
2 Research Square
Preprints are preliminary reports that have not undergone peer review.
They should not be considered conclusive, used to inform clinical practice,
or referenced by the media as validated information.

\title{
Pollution Levels, Sources and Risk Assessment of Polycyclic Aromatic Hydrocarbons in Farmland Soil and Crops Near Urumqi Industrial Park, Xinjiang, China
}

Xi Cui

Xinjiang University College of Resource and Environment Sciences

Nuerla Ailijiang ( $\square$ aljnel@xju.edu.cn)

Xinjiang University College of Resource and Environment Sciences

Yusuyunjiang Mamitimin

Xinjiang University College of Resource and Environment Sciences

Naifu Zhong

Xinjiang University College of Resource and Environment Sciences

Wenhu Cheng

Xinjiang University College of Resource and Environment Sciences

Nanxin Li

Xinjiang University College of Resource and Environment Sciences

Qiongfang Zhang

Xinjiang University College of Resource and Environment Sciences

Miao Pu

Xinjiang University College of Resource and Environment Sciences

\section{Research Article}

Keywords: Polycyclic aromatic hydrocarbon, Farmland soil, Crops, Source identification, Risk assessment

Posted Date: January 21st, 2022

DOl: https://doi.org/10.21203/rs.3.rs-1273637/v1

License: (a) (i) This work is licensed under a Creative Commons Attribution 4.0 International License. Read Full License 


\section{Abstract}

This study investigated the concentration, source, and risk assessment of polycyclic aromatic hydrocarbons (PAHs) in farmland soil and crops around the Urumqi Industrial Park in Xinjiang, China. The total concentration of 16 different PAHs in the soil and crop samples ranged between 2.32 and $225.11 \mathrm{ng} / \mathrm{g}$ and between 132.44 and $504.03 \mathrm{ng} / \mathrm{g}$ respectively, with average values of $39.29 \pm 2.39 \mathrm{ng} / \mathrm{g}$ for the soil samples and $295.81 \pm 105.00 \mathrm{ng} / \mathrm{g}$ for the crop samples. The source analysis of PAHs was performed using the positive matrix factorization and ratio method and identified the high-temperature combustion of fossil fuels, the volatilization of petroleum, coke oven emissions, and traffic emissions as main sources of PAHs in soil. The ecological risk posed by the PAHs detected in the soil samples was within a safe range. The incremental lifetime cancer risk (ILCR) value quantifies resulting from human exposure to soil containing PAH is at a safe level except for the potential carcinogenic risk to children due to ingestion exposure (ILCRs $>1.0 \times 10^{-6}$ ). The ILCR posed by crops exceed $1.0 \times 10^{-6}$ and the risk from sunflower crop was the highest. The highest ILCR values for each crop was observed for the adult female population. These results indicate that the farmland soil and crops near the Urumqi Industrial Park have been contaminated by PAHs and require urgent remediation to minimize adverse effects of exposure to carcinogens.

\section{Introduction}

Polycyclic aromatic hydrocarbons (PAHs) are persistent organic pollutants produced during the incomplete combustion of carbon-containing materials consisting of two or more benzene rings, such as wood, coal, gasoline, and diesel (Shen et al. 2011; Wang et al. 2021a). Due to their poor water solubility and good chemical stability, PAHs accumulate and persist in soil or atmosphere for a long time (Peng et al. 2011a; Yavar Ashayeri et al. 2018). PAHs in atmospheric particulate matter can further increase levels of PAHs in the soil through sedimentation. Therefore, the soil system is considered to be the main source of PAHs in the environment and affects the ecosystem and human health (Chen et al. 2017; Liu et al. 2018), and crops absorb PAHs from the soil during growth and development. PAH pollution has become a major environmental problem worldwide due to the potential carcinogenic, teratogenic, and mutagenic effects (Cao et al. 2019; Wang et al. 2017a).

With the rapid development of industry and the intensive consumption of fossil fuels, an increasing amount of PAHs are discharged into the environment. In recent years, many reports have focused on the concentration, source, spatial distribution and health risk assessment of PAHs in urban atmosphere and soil in domestic or international regions, including Chilean cities and suburbs (Apiratikul et al. 2021), Gandhi Plain (Jeba et al. 2021), North China (Liang et al. 2019), Moscow (Zavgorodnyaya et al. 2018), Iran Shiraz (Shahsavani et al. 2017), Uzbekistan (Bandowe et al. 2021), and Tianjin (Fan et al. 2021) (Jia et al. 2021; Zou et al. 2021). Although PAHs from the atmosphere and soil accumulate in crops, few researchers have investigated and analyzed this phenomenon. Diet has been identified as the main source of PAH exposure in humans, especially in non-smokers (Paris et al. 2018). Therefore, conducting sampling research on crops that are likely to be polluted by PAHs such as crops planted near industrial areas is crucial. The study and analysis of PAHs in the soil and cultivated plants near the e-waste treatment plant in Taizhou City, Zhejiang Province has shown that the three-and four-ring PAHs were easily absorbed by plants, and the higher molecular weight PAHs were prevented from being absorbed by root exudates and root bark (Wei et al. 2021). When sewage sludge is used for soil fertilization, the level of PAHs in soil increases and contributes to the excessive accumulation of PAHs in cultivated plants (Stańczyk-Mazanek et al. 2019). The average concentration of $\sum_{16}$ PAHs in four commonly consumed leafy vegetables in urban southern Nigeria ranged from $532 \mathrm{ng} / \mathrm{g}$ to $2261 \mathrm{ng} / \mathrm{g}$ (Tesi et al. 2021). In the contaminated soil and vegetable samples collected in Lagos, Nigeria, a sub-Saharan tropical environment, the total PAH concentrations in soil and vegetable samples were $200-250000 \mathrm{ng} / \mathrm{g}$ and $100-5000 \mathrm{ng} / \mathrm{g}$, respectively (Adetunde et al. 2018). A study by Xiong et al. (2017) analyzed the concentration of PAHs in cabbage outer leaf, core, and root near the Shanxi large coking plant and found that the order of PAH accumulation was outer leaf $>$ root $>$ core. These studies show that crops are affected by the amount of PAHs in the environment that do accumulate in the crops and harm them. Xinjiang, as the central area of the "Belt and Road Initiative," has developed rapidly in recent years, especially in heavy industries. However, research is necessary to evaluate PAHs in farmland soil and crops near industrial parks that have not been previously reported for this area.

In this study, we selected Midong Industrial Park in Urumqi as the research area to collect samples of surrounding farmland soil and important crops. The main aims of this study were: (1) to analyze the composition and pollution characteristics of PAHs in farmland soil and different types of crops, (2) to analyze the sources of PAHs in farmland soil, and (3) to assess risks associated with PAHs in farmland soils and different types of crops.

\section{Research Method}

\subsection{Study area}

The study area is located in the Midong District in the northeastern suburbs of Urumqi, northwest China. Natural disasters such as sandstorms and droughts are prevalent in this region (Simayi et al. 2018). The 216 National Highway, Dahuangshan Railway, and Petrochemical Railway pass through the boundary of the area, and the Tuwuda-Urumqi-Wukui Expressway intersects with these routes. The Midong district is rich in natural resources, including coal, siderite, limestone, petroleum, mirabilite, and other mineral resources, which has laid a solid industrial foundation (Dong and Yang 2014). These include several advantageous industries such as the chemical industry, coal and electricity, and machinery and equipment manufacturing. Highly developed transportation and industrial infrastructure release more PAHs into the environment. Urumqi is surrounded by mountains on three sides, which is not conducive to the natural dispersion of pollutants and causes them to accumulate in the environment (Li and Xie 2016; Mamtimin and Meixner 2011). In addition, the Midong district has a vast area of cultivated land and high crop yields. A significant amount of PAH present in the environment may potentially be absorbed by crops, posing health risks to humans. Therefore, the farmland surrounding the Midong Industrial Park was selected as the research area.

\subsection{Sampling and preparation}


From July 13 to 14, 2020, soil samples were collected from farmland near Midong Industrial Park. A total of 153 topsoil samples were collected (depth: 0 $20 \mathrm{~cm}$ ). Three soil samples (range: $2 \mathrm{~m} \times 2 \mathrm{~m}$ ) were collected at each sampling site as a sample mix. According to the planting characteristics of farmers and the eating habits of citizens, eight representative crops including onion, cabbage, coriander, beans, spinach, celery, lettuce, and sunflower were collected near sampling points 2,15 , and 41 . The distribution of the sampling points is shown in Fig. 1.

The collected soil and crop samples were spread in a dark basement, dried, ground in a mortar, and passed through a 100-mesh screen. Subsequently, $10 \mathrm{~g}$ of crop samples and $250 \mathrm{~g}$ of soil samples were collected, placed in opaque, white plastic bottles, sealed, and refrigerated at $-2^{\circ} \mathrm{C}$ for subsequent experimental analysis.

\subsection{Sample analysis}

The analysis procedure for soil, vegetable and water samples is the same. Fifteen grams of the sample was placed in a 250 -ml centrifuge tube; next, $30 \mathrm{ml}$ of mixed extraction solution $\left(V_{\text {dichloromethane }} / V_{\text {acetone }}=1: 1\right)$ was added to the tube and allowed to stand for $2 \mathrm{~h}$. The mixture after standing is beaten for 1 min in a digital display high-speed disperser (ULTRA-TURRAX), following which, the sample was placed in a digital display water bath constant temperature oscillator (SHA-C) at room temperature $\left(20^{\circ} \mathrm{C}\right)$ for $30 \mathrm{~min}$. Then, the mixture was placed in a high-speed centrifuge (CT18RT), centrifuged at $4^{\circ} \mathrm{C}$ and 1000 $\mathrm{r} / \mathrm{min}$ for $5 \mathrm{~min}$, and $5 \mathrm{ml}$ of supernatant was extracted and concentrated to near dryness. The volume was diluted to $2.5 \mathrm{ml}$ with $\mathrm{n}$-hexane and placed on an IKA vortex shaker (MS 3 digital) for $15 \mathrm{~s}$. Finally, the sample was passed through a $0.22-\mu$ filter membrane, waiting to assess.

An Agilent, 7890A-7000B, gas chromatograph mass spectrometer equipped with an HP5-MS column (30 $\mathrm{m} \times 250 \mu \mathrm{m} \times 0.25 \mu \mathrm{m})$ was used to assess the $\mathrm{PAH}$ contents and composition. High-purity helium was used as the carrier gas. Splitless injection was used, and the oven temperature was maintained over the course of the experiment as follows: an initial temperature of $60^{\circ} \mathrm{C}$ was maintained for $1 \mathrm{~min}$; the temperature was increased at a rate of $20^{\circ} \mathrm{C} / \mathrm{min}$ to $180^{\circ} \mathrm{C}$ for $2 \mathrm{~min}$, the temperature was increased at a rate of $8^{\circ} \mathrm{C} / \mathrm{min}$ to $240^{\circ} \mathrm{C}$ for $2 \mathrm{~min}$; the temperature was increased at a rate of $5^{\circ} \mathrm{C} / \mathrm{min}$ to $279^{\circ} \mathrm{C}$ for 10 $\mathrm{min}$, and finally increased at a rate of $10^{\circ} \mathrm{C} / \mathrm{min}$ to $300^{\circ} \mathrm{C}$ for $8 \mathrm{~min}$. An electron bombardment source was used for ionization and ion monitoring mode acquired data.

\subsection{Quality control}

The entire experimental process was conducted according to the sample recovery rate, parallel sample, sample blank, and standard addition blank for quality control. The PAHs detected in the blank samples were below the instrument detection limit as expected. The method detection limits of different samples are shown in Table 1. Tritium was added as an internal standard to measure the samples. The spiked recovery rates of the 16 PAHs in the samples ranged from $75.64-115.89 \%$. The relative standard deviation was $3.4-9.7 \%$. All samples were corrected for recovery, and the PAH content of the blank samples was also determined.

\subsection{Source analysis method}

In the source analysis of PAHs, the positive matrix factorization (PMF) method was mainly used for quantitative analysis, and the diagnostic ratio method was used for qualitative analysis.

In this study, the isomer ratios of the following PAH isomers were used to analyze the PAH pollution sources in the soil samples: FLA/(FLA + PYR), $\mathrm{ANT} /(\mathrm{ANT}+\mathrm{PHE}), \mathrm{BaA} /(\mathrm{BaA}+\mathrm{CHR})$, and $\operatorname{lnP} /(\mathrm{InP}+\mathrm{BghiP})$. A ratio analysis of the following: ANT/(ANT + PHE) $<0.1, \mathrm{FLA} /(\mathrm{FLA}+\mathrm{PYR})<0.4, \mathrm{BaA} /(\mathrm{BaA}+$ $\mathrm{CHR})<0.2$ and $\mathrm{InP} /(\mathrm{InP}+\mathrm{BghiP})<0.2$ indicated that the main source of the PAHs was oil. The ratio ANT/(ANT $+\mathrm{PHE})>0.1$ shows that the representative combustion source is also the main combustion source. The values of the ratios FLA/(FLA + PYR $)>0.5, \mathrm{BaA} /(\mathrm{BaA}+\mathrm{CHR})>0.35$ and $\operatorname{lnP} /(\operatorname{InP}+\mathrm{BghiP})>$ 0.5 , indicate that the main source of PAHs was the burning of biomass such as grass, wood and coal; when the inverse ratios would represent the main source of PAHs being oil combustion 0.4< FLA/(FLA + PYR $)<0.5,0.2<\mathrm{BaA} /(\mathrm{BaA}+\mathrm{CHR})<0.35,0.2<\operatorname{InP} /(\operatorname{lnP}+\mathrm{BghiP})<0.5(\mathrm{Lu}$ et al. $2019 ; \mathrm{Wang}$ et al. 2021b).

We used the PMF model to identify the main sources of PAHs quantitatively according to the composition of the 16 different PAHs in the soil samples. The PMF model estimates the composition of pollution sources and their contribution to environmental concentrations of pollutants according to a large dataset of observations at receptor points. The basic equation of the PMF model is $X=G F+E$. This means that the matrix of the speciation sample data is decomposed into two matrix factors (Callen et al. 2014; Magesh et al. 2021): the factor contribution (G) and the factor spectrum (F). The objective function of the PMF model is expressed as follows.

$$
\mathrm{Q}=\sum_{i=1}^{n} \sum_{j=1}^{m}\left(\frac{E_{i j}}{u_{i j}}\right)^{2}
$$

$2-1$

In the formula: $u_{i j}$ is the uncertainty of the $j^{t h}$ species in the $i^{t h}$ sample; $\mathrm{n}$ is the number of samples; $\mathrm{m}$ is the number of species; $\mathrm{E}$ is the residual matrix, representing the difference between $\mathrm{X}$ and GF.

The PMF model performs iterative calculations based on the least squares method and continuously decomposes the original matrix $X$ to obtain the optimal matrices $\mathrm{G}$ and $\mathrm{F}$. The goal of optimization was to make $\mathrm{Q}$ tend to the value of the number of degrees of freedom.

\subsection{Risk assessment}


To evaluate the ecological risk assessment of PAHs in soil, the equivalent concentration (TEQ) of PAHs is converted from the benzo[a]pyrene (BaP) toxicity equivalence factor (TEF) which is defined as follows (Fang et al. 2004; Nadal et al. 2004; Tsai et al. 2001):

$$
\mathrm{TEQ}=\sum\left(\mathrm{PAH}_{\mathrm{i}} \times \mathrm{TEF}_{\mathrm{i}}\right)
$$

$2-2$

To assess the possible carcinogenic risk caused by PAHs in the soil to the human body, the risk values of the three exposure pathways (ingestion, dermal contact and inhalation) were calculated according to the incremental lifetime carcinogenic risk (ILCR) model recommended by the EPA (De Miguel et al. 2007; Liang et al. 2019; Peng et al. 2011b; Qi et al. 2020; Zhang et al. 2015). The formula is as follows:

$$
\mathrm{ILCRs}_{\text {Ingestion }}=\frac{C S \times\left(C S F_{\text {Ingestion }} \times \sqrt[3]{\left(\frac{B W}{70}\right)}\right) \times I R_{\text {Ingestion }} \times E F \times E D}{B W \times A T \times 10^{6}}
$$

2-3

$$
\text { ILCRs }_{\text {Dermal }}=\frac{C S \times\left(C S F_{\text {Dermal }} \times \sqrt[3]{\left(\frac{B W}{70}\right)}\right) \times S A \times A B S \times E F \times E D}{B W \times A T \times P E F}
$$

$2-4$

$$
\text { ILCRs }_{\text {Inhalation }}=\frac{C S \times\left(C S F_{\text {Inh alation }} \times \sqrt[3]{\left(\frac{B W}{70}\right)}\right) \times I R_{\text {Inh alation }} \times E F \times E D}{B W \times A T \times P E F}
$$

2-5

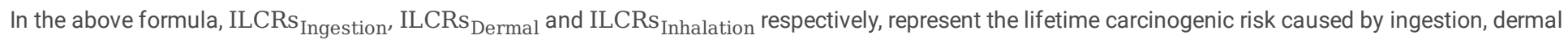

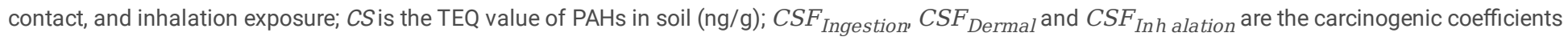
of ingestion, dermal contact and inhalation of $\mathrm{BaP}$ respectively. $B W$ is the body weight $(\mathrm{kg})$ of the exposed population. $I R_{I n g e s t i o n}$ is the ingestion rate $\left(\mathrm{mg} /\right.$ day); $S A$ is dermal exposure rate (ma/day); $A B S$ is a carcinogen absorbed by dermal and $I R_{\text {Inh alation }}$ is the inhalation rate $\left(\mathrm{m}^{3} / \mathrm{day}\right) . E F$ is the frequency of exposure (day/year); $E D$ is the years of exposure (year); $A T$ stands for average life expectancy (70 years or 25,550 days) and $P E F$ is the particulate emission factor ( $\mathrm{m}^{3} /$ day).;

The following formula was used to evaluate the health risks to different groups of people caused by consumption of contaminated vegetables (Liao and Chiang 2006):

$$
E_{D}=\frac{B E C \times I R \times \square 1-W \square}{B W}
$$

2-6

$$
\mathrm{ILCR}=\frac{E_{D} \times E F \times E D \times S F \times C F}{A T}
$$

$2-7$

In the above formula: $E_{D}$ is the daily intake of PAHs into the human body through ingestion (ng/g • day); $I R$ is the daily intake of vegetables (g/d); $W$ is vegetable moisture content (\%); $B W$ is the body weight $(\mathrm{kg}) ; E F$ is the exposure frequency (365 days); $E D$ is exposure time (years); $S F$ was the oral slope factor of $\mathrm{BaP}\left(1 /(\mathrm{mg} / \mathrm{kg} \cdot\right.$ day) $)$; $C F$ is the conversion coefficient $\left(10^{-6} \mathrm{mg} / \mathrm{ng}\right) ; A T$ stands for average life expectancy (70 years or 25,550 days).

The corresponding parameters for calculation were selected according to the ILCR model (Peng et al. 2011a; Soltani et al. 2015). According to this model, values less than $1.0 \times 10^{-6}$ are an acceptable risk; values between $1.0 \times 10^{-6}$ and $1.0 \times 10^{-4}$ indicate that there is a potential cancer risk, and when the values are greater than $1.0 \times 10^{-4}$, it indicates that there is a high cancer risk to the human body (Maertens et al. 2008).

\section{Results And Discussion}

\subsection{Pollution characteristics of PAHs in farmland soil and crop samples}


A summary of the PAH concentrations of 51 farmland soil samples from the Midong Industrial Park is shown in Table 2 . The 16 PAHs prioritized by the US EPA were all detected in the samples, and the total concentration ranged from 2.32 to $225.11 \mathrm{ng} / \mathrm{g}$. Of all the monomeric PAHs of all the samples, the content of PHE was the highest (538.46 ng/g), followed by FLA (298.53 ng/g), and the lowest was ACY (10.82 ng/g). Compared with those in farmland soils in other regions, the average content of PAHs in the soil around Midong Industrial Park (39.29 $\pm 2.39 \mathrm{ng} / \mathrm{g})$ was lower than that in East Africa Kenya (3353.04 $\pm 2179.81 \mathrm{ng} / \mathrm{g}$ ) (Mungai et al. 2018), Shanghai (1552 ng/g) (Tong et al. 2018), Jilin (877.23 ng/g) (Chen et al. 2018) and Ningde (406 ng/g) (Zheng et al. 2019), and other regions (Ge et al. 2017). The relative molecular mass gradient of PAHs in the soil was as follows: 4 rings $>3$ rings $>5$ rings $>6$ rings $>2$ rings (Fig. 2). This was consistent with the relevant research conducted on farmland soil near an industrial zone in Nigeria (Anietie and Godwin 2016).

The concentrations of PAHs in 11 different crop samples collected around the industrial park are shown in Table 3. The PAH contents of the crop samples ranged from 132.44 to $504.03 \mathrm{ng} / \mathrm{g}$, with an average value of $295.81 \pm 105.00 \mathrm{ng} / \mathrm{g}$. In the seven leaf crop samples, the PAH content was in the following order: Onion $(504.43 \mathrm{ng} / \mathrm{g})>$ Cabbage $(363.33 \mathrm{ng} / \mathrm{g})>$ Lettuce $(357.18 \mathrm{ng} / \mathrm{g})>$ Sunflower leaves $(352.64 \mathrm{ng} / \mathrm{g})>$ Spinach $(210.69 \mathrm{ng} / \mathrm{g})>$ Coriander $(191.32$ $\mathrm{ng} / \mathrm{g})>$ Celery $(132.44 \mathrm{ng} / \mathrm{g})$. There was little difference in the content of PAHs in fruit crop samples, which were beans (242.12 ng/g) and sunflower fruit $(247.95 \mathrm{ng} / \mathrm{g})$. The PAH concentration in two root crop samples were onion root $(366.72 \mathrm{ng} / \mathrm{g})>$ sunflower root $(285.13 \mathrm{ng} / \mathrm{g})$. Among the PAHs present in all the crop samples, PHE had the highest concentration, followed by FLU. BghiP was not detected in any of the crop samples. The amount of PAH present varies in different parts of the same crop. For example: PAHs in onion > PAHs in onion root, PAHs in sunflower leaves > PAHs in sunflower root > PAHs in sunflower fruit. In crop samples, the low molecular weight PAHs ( $\leq 4$-rings) dominate, reaching $99 \%$ of the total PAH content, while high molecular weight PAHs accounted for only $1 \%$ (Fig. 2). PAHs with more than four rings are strongly adsorbed on organic matter, and the absorption rate of plants is low (Paris et al. 2018). This was consistent with the results of previous studies (Jia et al. 2018; Wang et al. 2017b; Waqas et al. 2014).

\subsection{Source analysis of PAHs in farmland soil}

The PMF was used to model the data and to identify quantitatively the source of the PAHs. The PMF model identified four significant sources: the hightemperature burning of fossil fuels, oil volatilization and leakage, coke oven emissions, and traffic emissions (Fig. 3). The corresponding contribution rates were $56.2 \%, 10.5 \%, 22.8 \%$, and $10.5 \%$, respectively (Fig. 4). The source analysis spectrum for each factor is shown in Fig. 5 .

In Factor 1, PAHs with 4 to 6 rings were dominant. The fingerprint spectra of compounds such as CHR and BaA were similar to those of PAHs emitted by coal burning in northern China (Manoli et al. 2004; Wu et al. 2014). Studies have also shown that BaA is a marker compound of natural gas combustion (Islam and Saikia 2020), and BbF, BkF, and BghiP are markers of gasoline combustion. BaA, CHR, and BbF also appear in the exhaust gas of diesel combustion (Liu et al. 2017a; Yang et al. 2013). Therefore, Factor 1 should represent the source of the high-temperature burning of fossil fuels (coal burning and transport emissions). In Factor 2, ACY and ACE accounted for a large proportion of the PAHs, followed by NAPH. Literature shows that crude oil, machine lubricants, and other petroleum derivatives are prone to produce $2-3$ ring PAHs monomers such as ACY, ACE, and NAPH which is a characteristic compound of oil spills frequently used as an indicator (Dong and Lee 2009; Khairy and Lohmann 2013; Wang et al. 2006). Therefore, we infer that Factor 2 is related to oil volatilization and leakage. Factor 3 contains high levels of FLU, ANT, and PHE. Studies have shown that FLU and PHE are more common in coke oven emissions (Liu et al. 2017b; Wang et al. 2015). Therefore, Factor 3 was attributed to coke oven emissions. In Factor 4, InP and DBA accounted for a large proportion of the variance. InP is the characteristic compound indicating a diesel combustion source (Hu et al. 2017), whereas DBA is an indicator for gasoline combustion. Thus, Factor 4 represents the traffic PAH emission source.

The ratio method was used for the qualitative analysis of the PAH sources in the soil, as shown in Fig. 6. The ANT/(ANT + PHE) ratios for all soil samples were greater than 0.1 , except for a few sampling points, which indicates a combustion source. The FLA/(FLA + PYR) ratios were greater than 0.5, and most samples had a $\mathrm{BaA} /(\mathrm{BaA}+\mathrm{CHR})$ ratio greater than 0.35 , which indicates the PAH source is the combustion of grass, wood, coal, and coke. A ratio of $\mathrm{InP} /(\ln \mathrm{P}+\mathrm{BghiP})$ less than 0.5 , indicates an oil combustion source that is usually due to transportation emissions. The ratio and PMF methods reached the same conclusion: the main sources of PAHs are oil spills, coke burning, high-temperature burning of fossil fuels, and transport emissions.

\subsection{Risk assessment of PAHs in soil and crops}

\subsubsection{Risk assessment of PAHs in soil}

By comparing the TEQ values of all the sampling points (Table 4), the BAP toxicity was still the highest in the soil samples, followed by the toxicity of DBA. However, the TEQ values of all samples were much lower than the safety value of $700 \mathrm{ng} / \mathrm{g}$ set by the Canadian government (Liu et al. 2018). The range of ILCR due to human exposure to PAHs in soil was between $1.46 \times 10^{-10}$ and $1.03 \times 10^{-5}$ (Table 5). The highest carcinogenic risk posed by PAHs was ingestion exposure, followed by dermal contact and inhalation exposure. The ILCR for children due to ingestion exposure to PAHs, exceeded $1.0 \times 10^{-6}$, indicating a potential carcinogenic risk to children. In the other two exposure pathways (dermal contact and inhalation exposure), the ILCR was greater for adults than that for children, but they were within safe ranges (less than $1.0 \times 10^{-6}$ ).

\subsubsection{Health risk assessment of PAHs in crops}

Daily exposure to PAHs varies greatly among different populations due to the consumption of different crops. The largest daily exposure of PAHs through ingestion was due to the consumption of sunflower $(1.08-4.25 \mathrm{ng} / \mathrm{g} \bullet \mathrm{kg})$, followed by spinach $(1.01-2.04 \mathrm{ng} / \mathrm{g} \bullet \mathrm{kg}$, and onions $(0.89-1.79 \mathrm{ng} / \mathrm{g} \bullet \mathrm{kg}$ ). The daily exposure due to lettuce consumption was the lowest $(0.23-0.45 \mathrm{ng} / \mathrm{g} \bullet \mathrm{kg}$ ) (See Table 6). The daily exposure values of different crops mainly depended on their toxic equivalents or TEQ values that were a result of the amount of PAH present in the plant material. The higher the TEQ value, the greater the exposure to PAH through ingestion. In addition, the moisture content of crops can affect the daily exposure to PAH as crops with low water content have an increased proportion of dry weight.

Page 5/17 
The ILCRs produced by different people eating different crops are shown in Table 7. Adults and children ingest all crops, all of which can pose potential carcinogenic risks (ILCRs $\left.>1.0 \times 10^{-6}\right)$. Among all population groups the risk of cancer caused by the consumption of sunflowers was the highest and was greater than $1.0 \times 10^{-6}$, which indicated a potential carcinogenic risk. In addition to sunflowers (ILCRs $>1.0 \times 10^{-6}$ ), teenagers eat other crops at a safe level $\left(\right.$ ILCRs $\left.<1.0 \times 10^{-6}\right)$. This may be because teenagers have higher metabolisms and can rely on their bodies to digest a small amount of PAHs. The highest ILCR values of all crops were observed in adult women. It may be that adult females have higher daily exposure to crops than other groups.

\section{Conclusion}

The total concentrations of 16 different PAHs in soil and crop samples from farmland surrounding Midong Industrial Park in Urumqi are 2.32 to $225.11 \mathrm{ng} / \mathrm{g}$ and 132.44 to $504.03 \mathrm{ng} / \mathrm{g}$ respectively, with average values of $39.29 \pm 2.39 \mathrm{ng} / \mathrm{g}$ and $295.81 \pm 105.00 \mathrm{ng} / \mathrm{g}$. In the crop samples, low molecular weight $\mathrm{PAHs}$ ( $\leq 4$-rings) were predominant. The source analysis showed that the PAHs in the soil mainly came from the high-temperature combustion of fossil fuels, the volatilization of petroleum, coke oven emissions, and traffic emissions. The ecological risk of the soil samples was at a safe level. The ILCR value due to human ingestion exposure to soil has a potential carcinogenic risk for children who were more likely to eat soil while other groups had a safe level of exposure. Regarding the ILCR value due to crops, the highest risk was due to sunflower consumption. All crops were found to have ILCR values exceeding $1.0 \times 10^{-6}$. The highest ILCR values due to consumption of crops were observed in adult female population group. In summary, PAH pollution in the farmland soil and crops near Midong Industrial Park in Urumqi was detected. The concentrations detected were above safety levels for certain crops and population groups but not all. Relevant policies should be implemented to reduce PAH pollution and prevent worsening the population groups' carcinogenic risk values.

\section{Declarations}

Competing Interests:There are no known competing financial interests or personal relationships that might affect the work described here. There are no financial interests or personal relationships that can be construed as potential competitive interests.

Author Contributions: Xi Cui: Investigation, Methodology, Conducting the experiment, Data collation and analysis, Writing - original draft. Nuerla Ailijiang: Investigation, Supervision, Conceptualization, Writing - review \& editing, Formal analysis. Yusuyunjiang Mamitimin: Writing - review \& editing. Naifu Zhong: Assisted in the experiment. Wenhu Cheng: Helped with the sample collection. Nanxin Li: Assisted in the experiment. Qiongfang Zhang: Helped with the sample collection. Miao Pu: Helped with the sample collection.

The author confirms that the author group, corresponding author, and author order at the time of submission are correct and will not be changed later.

Ethical Responsibilities of Authors: This article is the authors' original innovative work. Neither the full text nor a part of it has been published or accepted elsewhere. It has not been submitted to any other journal, nor has it previously been submitted to the Stochastic Environmental Research and Risk Assessment.

The findings of this paper do not involve fabrication, falsification, or improper manipulation of data (including image-based manipulation). The authors followed scientifically specific rules for obtaining, selecting, and processing data.

This is a research paper that cites relevant literature to support the proposed ideas. The article does not pose a threat to public health or national security due to misuse.

The paper does not involve studies of Human Participants and/or Animals.

Informed Consent: This paper was submitted and published with the informed consent of all authors.

Data transparency[Data may be obtained from the authors upon request.

Acknowledgment: We gratefully acknowledged financial support provided by the National Natural Science Foundation of China [grant No. 51968067], the Natural Science Foundation of Xinjiang Uygur Autonomous Region of China [grant No. 2018D01C044], and State Key Laboratory of Pollution Control and Resource Reuse Foundation, [grant No. PCRRF19013].

\section{References}

1. Adetunde, O.T., Mills, G.A., Oluseyi, T.O., Oyeyiola, A.O., Olayinka, K.O. and Alo, B.I. (2018) Polycyclic Aromatic Hydrocarbon in Vegetables Grown on Contaminated Soils in a Sub-Saharan Tropical Environment - Lagos, Nigeria. Polycyclic Aromatic Compounds 40(4), $979-989$. http://doi.org/10.1080/10406638.2018.1517807

2. Anietie, M. and Godwin, E. (2016) Risk Assessment of Polycyclic Aromatic Hydrocarbons PAHs in Soils and Tubers Crops Collected from Ikot Oborenyin, South-south Nigeria. International Research Journal of Pure and Applied Chemistry 10(2), 1-13. http://doi.org/10.9734/irjpac/2016/20154

3. Apiratikul, R., Pongpiachan, S. and Deelaman, W. (2021) Spatial distribution, sources and quantitative human health risk assessments of polycyclic aromatic hydrocarbons in urban and suburban soils of Chile. Environ Geochem Health 43(8), 2851-2870. http://doi.org/10.1007/s10653-020-00798-7

4. Bandowe, B.A.M., Shukurov, N., Leimer, S., Kersten, M., Steinberger, Y. and Wilcke, W. (2021) Polycyclic aromatic hydrocarbons (PAHs) in soils of an industrial area in semi-arid Uzbekistan: spatial distribution, relationship with trace metals and risk assessment. Environ Geochem Health 43(11), 48474861. http://doi.org/10.1007/s10653-021-00974-3

Page 6/17 
5. Callen, M.S., Iturmendi, A., Lopez, J.M. and Mastral, A.M. (2014) Source apportionment of the carcinogenic potential of polycyclic aromatic hydrocarbons (PAH) associated to airborne PM10 by a PMF model. Environ Sci Pollut Res Int 21(3), 2064-2076. http://doi.org/10.1007/s11356-0132116-9

6. Cao, W., Yin, L., Zhang, D., Wang, Y., Yuan, J., Zhu, Y. and Dou, J. (2019) Contamination, Sources, and Health Risks Associated with Soil PAHs in Rebuilt Land from a Coking Plant, Beijing, China. Int J Environ Res Public Health 16(4). http://doi.org/10.3390/ijerph16040670

7. Chen, W., Wang, H., Gao, Q., Chen, Y., Li, S., Yang, Y., Werner, D., Tao, S. and Wang, X. (2017) Association of 16 priority polycyclic aromatic hydrocarbons with humic acid and humin fractions in a peat soil and implications for their long-term retention. Environ Pollut 230, 882-890. http://doi.org/10.1016/j.envpol.2017.07.038

8. Chen, Y., Zhang, J., Zhang, F., Li, F. and Zhou, M. (2018) Polycyclic aromatic hydrocarbons in farmland soils around main reservoirs of Jilin Province, China: occurrence, sources and potential human health risk. Environ Geochem Health 40(2), 791-802. http://doi.org/10.1007/s10653-017-0024-5

9. De Miguel, E., Iribarren, I., Chacon, E., Ordonez, A. and Charlesworth, S. (2007) Risk-based evaluation of the exposure of children to trace elements in playgrounds in Madrid (Spain). Chemosphere 66(3), 505-513. http://doi.org/10.1016/j.chemosphere.2006.05.065

10. Dong, T.T.T. and Lee, B.-K. (2009) Characteristics, toxicity, and source apportionment of polycylic aromatic hydrocarbons (PAHs) in road dust of Ulsan, Korea. Chemosphere 74(9), 1245-1253. http://doi.org/10.1016/j.chemosphere.2008.11.035

11. Dong, W. and Yang, Y. (2014) Exploitation of mineral resource and its influence on regional development and urban evolution in Xinjiang, China. Journal of Geographical Sciences 24(6), 1131-1146. http://doi.org/10.1007/s11442-014-1143-x

12. Fan, Y., Zhao, Z., Shi, R., Li, X., Yang, Y. and Lan, J. (2021) Urbanization-related changes over the last 20 years in occurrence, sources, and human health risks of soil PAHs in rural Tianjin, China. Environmental Chemistry Letters 19(6), 3999-4008. http://doi.org/10.1007/s10311-021-01264-1

13. Fang, G.C., Chang, K.F., Lu, C.S. and Bai, H.L. (2004) Estimation of PAHs dry deposition and BaP toxic equivalency factors (TEFs) study at Urban, Industry Park and rural sampling sites in central Taiwan, Taichung. Chemosphere 55(6), 787-796. http://doi.org/10.1016/j.chemosphere.2003.12.012

14. Ge, W., Cheng, Q.-q., Chai, C., Zeng, L.-s., Wu, J., Chen, Q.-h., Zhu, X.-w. and Ma, D. (2017) Pollution Characteristics and Source Analysis of Polycyclic Aromatic Hydrocarbons in Agricultural Soils from Shandong. Huanjing Kexue 38(4), 1587-1596. http://doi.org/10.13227/j.hjkx.201608199

15. Hu, J., Liu, C., Guo, Q., Yang, J., Okoli, C.P., Lang, Y., Zhao, Z., Li, S., Liu, B. and Song, G. (2017) Characteristics, source, and potential ecological risk assessment of polycyclic aromatic hydrocarbons (PAHs) in the Songhua River Basin, Northeast China. Environmental Science and Pollution Research 24(20), 17090-17102. http://doi.org/10.1007/s11356-017-9057-7

16. Islam, N. and Saikia, B.K. (2020) Atmospheric particulate matter and potentially hazardous compounds around residential/road side soil in an urban area. Chemosphere 259, 127453. http://doi.org/10.1016/j.chemosphere.2020.127453

17. Jeba, F., Karim, T.T., Khan, M.F., Latif, M.T., Quddus, K.F. and Salam, A. (2021) Receptor modelling and risk factors of polycyclic aromatic hydrocarbons (PAHs) in the atmospheric particulate matter at an IGP outflow location (island of the bay of Bengal-Bhola, Bangladesh). Air Quality, Atmosphere \& Health 14(9), 1417-1431. http://doi.org/10.1007/s11869-021-01031-9

18. Jia, J., Bi, C., Zhang, J., Jin, X. and Chen, Z. (2018) Characterization of polycyclic aromatic hydrocarbons (PAHs) in vegetables near industrial areas of Shanghai, China: Sources, exposure, and cancer risk. Environ Pollut 241, 750-758. http://doi.org/10.1016/j.envpol.2018.06.002

19. Jia, T., Guo, W., Xing, Y., Lei, R., Wu, X., Sun, S., He, Y. and Liu, W. (2021) Spatial distributions and sources of PAHs in soil in chemical industry parks in the Yangtze River Delta, China. Environ Pollut 283, 117121. http://doi.org/10.1016/j.envpol.2021.117121

20. Khairy, M.A. and Lohmann, R. (2013) Source apportionment and risk assessment of polycyclic aromatic hydrocarbons in the atmospheric environment of Alexandria, Egypt. Chemosphere 91(7), 895-903. http://doi.org/10.1016/j.chemosphere.2013.02.018

21. Li, S. and Xie, S. (2016) Spatial distribution and source analysis of SO2 concentration in Urumqi. International Journal of Hydrogen Energy 41(35), 15899-15908. http://doi.org/10.1016/j.ijhydene.2016.04.142

22. Liang, M., Liang, H., Rao, Z. and Hong, X. (2019) Characterization of polycyclic aromatic hydrocarbons in urban-rural integration area soil, North China: Spatial distribution, sources and potential human health risk assessment. Chemosphere 234, 875-884.

http://doi.org/10.1016/j.chemosphere.2019.06.119

23. Liao, C.M. and Chiang, K.C. (2006) Probabilistic risk assessment for personal exposure to carcinogenic polycyclic aromatic hydrocarbons in Taiwanese temples. Chemosphere 63(9), 1610-1619. http://doi.org/10.1016/j.chemosphere.2005.08.051

24. Liu, H., Yu, X.L., Liu, Z.R. and Sun, Y. (2018) Occurrence, characteristics and sources of polycyclic aromatic hydrocarbons in arable soils of Beijing, China. Ecotoxicology and Environmental Safety 159, 120-126. http://doi.org/10.1016/j.ecoenv.2018.04.069

25. Liu, N., Li, X., Zhang, D., Liu, Q., Xiang, L., Liu, K., Yan, D. and Li, Y. (2017a) Distribution, sources, and ecological risk assessment of polycyclic aromatic hydrocarbons in surface sediments from the Nantong Coast, China. Marine Pollution Bulletin 114(1), 571-576.

http://doi.org/10.1016/j.marpolbul.2016.09.020

26. Liu, W., Ma, L., Abuduwaili, J. and Li, Y. (2017b) Distribution, source analysis, and ecological risk assessment of polycyclic aromatic hydrocarbons in the typical topsoil of the Issyk-Kul Lake Basin. Environ Monit Assess 189(8), 398. http://doi.org/10.1007/s10661-017-6113-1

27. Lu, J., Zhang, C., Wu, J., Lin, Y., Zhang, Y., Yu, X. and Zhang, Z. (2019) Pollution, sources, and ecological-health risks of polycyclic aromatic hydrocarbons in coastal waters along coastline of China. Human and Ecological Risk Assessment: An International Journal 26(4), 968-985. http://doi.org/10.1080/10807039.2018.1548899

28. Maertens, R.M., Yang, X.F., Zhu, J.P., Gagne, R.W., Douglas, G.R. and White, P.A. (2008) Mutagenic and carcinogenic hazards of settled house dust I: Polycyclic aromatic hydrocarbon content and excess lifetime cancer risk from preschool exposure. Environmental Science \& Technology 42(5), 1747- 
1753. http://doi.org/10.1021/es702449c

29. Magesh, N.S., Tiwari, A., Botsa, S.M. and da Lima Leitao, T. (2021) Hazardous heavy metals in the pristine lacustrine systems of Antarctica: Insights from PMF model and ERA techniques. J Hazard Mater 412, 125263. http://doi.org/10.1016/j.jhazmat.2021.125263

30. Mamtimin, B. and Meixner, F.X. (2011) Air pollution and meteorological processes in the growing dryland city of Urumqi (Xinjiang, China). Sci Total Environ 409(7), 1277-1290. http://doi.org/10.1016/j.scitotenv.2010.12.010

31. Manoli, E., Kouras, A. and Samara, C. (2004) Profile analysis of ambient and source emitted particle-bound polycyclic aromatic hydrocarbons from three sites in northern Greece. Chemosphere 56(9), 867-878. http://doi.org/10.1016/j.chemosphere.2004.03.013

32. Mungai, T.M., Yan, X., Makokha, V.A., Githaiga, K.B. and Wang, J. (2018) Concentrations, source identification and eco-toxicological risk of polycyclic aromatic hydrocarbons in agricultural soils of Kenya, Eastern Africa. International Journal of Environmental Science and Technology 16(8), $4303-4314$. http://doi.org/10.1007/s13762-018-2014-2

33. Nadal, M., Schuhmacher, M. and Domingo, J.L. (2004) Levels of PAHs in soil and vegetation samples from Tarragona County, Spain. Environmental Pollution 132(1), 1-11. http://doi.org/10.1016/j.envpol.2004.04.003

34. Paris, A., Ledauphin, J., Poinot, P. and Gaillard, J.L. (2018) Polycyclic aromatic hydrocarbons in fruits and vegetables: Origin, analysis, and occurrence. Environ Pollut 234, 96-106. http://doi.org/10.1016/j.envpol.2017.11.028

35. Peng, C., Chen, W., Liao, X., Wang, M., Ouyang, Z., Jiao, W. and Bai, Y. (2011a) Polycyclic aromatic hydrocarbons in urban soils of Beijing: status, sources, distribution and potential risk. Environ Pollut 159(3), 802-808. http://doi.org/10.1016/j.envpol.2010.11.003

36. Peng, C., Chen, W., Liao, X., Wang, M., Ouyang, Z., Jiao, W. and Bai, Y. (2011b) Polycyclic aromatic hydrocarbons in urban soils of Beijing: Status, sources, distribution and potential risk. Environmental Pollution 159(3), 802-808. http://doi.org/10.1016/j.envpol.2010.11.003

37. Qi, P., Qu, C., Albanese, S., Lima, A., Cicchella, D., Hope, D., Cerino, P., Pizzolante, A., Zheng, H., Li, J. and De Vivo, B. (2020)Investigation of polycyclic aromatic hydrocarbons in soils from Caserta provincial territory, southern Italy: Spatial distribution, source apportionment, and risk assessment. Journal of Hazardous Materials 383, 121158. http://doi.org/10.1016/j.jhazmat.2019.121158

38. Shahsavani, S., Hoseini, M., Dehghani, M. and Fararouei, M. (2017) Characterisation and potential source identification of polycyclic aromatic hydrocarbons in atmospheric particles (PM10) from urban and suburban residential areas in Shiraz, Iran. Chemosphere 183, 557-564.

http://doi.org/10.1016/j.chemosphere.2017.05.101

39. Shen, G., Wang, W., Yang, Y., Ding, J., Xue, M., Min, Y., Zhu, C., Shen, H., Li, W., Wang, B., Wang, R., Wang, X., Tao, S. and Russell, A.G. (2011) Emissions of PAHs from Indoor Crop Residue Burning in a Typical Rural Stove: Emission Factors, Size Distributions, and Gas-Particle Partitioning. Environmental Science \& Technology 45(4), 1206-1212. http://doi.org/10.1021/es102151w

40. Simayi, M., Yahefu, P. and Han, M. (2018) Spatiotemporal Variation, Source Analysis, and Health Risk Assessment of Particle-bound PAHs in Urumqi, China. Aerosol and Air Quality Research 18(11), 2728-2740. http://doi.org/10.4209/aaqr.2018.04.0151

41. Soltani, N., Keshavarzi, B., Moore, F., Tavakol, T., Lahijanzadeh, A.R., Jaafarzadeh, N. and Kermani, M. (2015) Ecological and human health hazards of heavy metals and polycyclic aromatic hydrocarbons (PAHs) in road dust of Isfahan metropolis, Iran. Science of the Total Environment 505, 712-723. http://doi.org/10.1016/j.scitotenv.2014.09.097

42. Stańczyk-Mazanek, E., Stępniak, L. and Kępa, U. (2019) Analysis of Migration of Polycyclic Aromatic Hydrocarbons from Sewage Sludge Used for Fertilization to Soils, Surface Waters, and Plants. Water 11(6), 1270. http://doi.org/10.3390/w11061270

43. Tesi, G.O., Iniaghe, P.O., Lari, B., Obi-lyeke, G. and Ossai, J.C. (2021) Polycyclic aromatic hydrocarbons (PAHs) in leafy vegetables consumed in southern Nigeria: concentration, risk assessment and source apportionment. Environ Monit Assess 193(7), 443. http://doi.org/10.1007/s10661-021-09217-5

44. Tong, R., Yang, X., Su, H., Pan, Y., Zhang, Q., Wang, J. and Long, M. (2018) Levels, sources and probabilistic health risks of polycyclic aromatic hydrocarbons in the agricultural soils from sites neighboring suburban industries in Shanghai. Sci Total Environ 616-617, 1365-1373. http://doi.org/10.1016/j.scitotenv.2017.10.179

45. Tsai, P.J., Shieh, H.Y., Lee, W.J. and Lai, S.O. (2001) Health-risk assessment for workers exposed to polycyclic aromatic hydrocarbons (PAHs) in a carbon black manufacturing industry. Science of the Total Environment 278(1-3), 137-150. http://doi.org/10.1016/s0048-9697(01)00643-x

46. Wang, C., Wu, S., Zhou, S.L., Wang, H., Li, B., Chen, H., Yu, Y. and Shi, Y. (2015) Polycyclic aromatic hydrocarbons in soils from urban to rural areas in Nanjing: Concentration, source, spatial distribution, and potential human health risk. Sci Total Environ 527-528, 375-383.

http://doi.org/10.1016/j.scitotenv.2015.05.025

47. Wang, C.H., Wu, S.H., Zhou, S.L., Sill, Y.X. and Song, J. (2017a) Characteristics and Source Identification of Polycyclic Aromatic Hydrocarbons (PAHs) in Urban Soils: A Review. Pedosphere 27(1), 17-26. http://doi.org/10.1016/s1002-0160(17)60293-5

48. Wang, J., Zhang, X., Ling, W., Liu, R., Liu, J., Kang, F. and Gao, Y. (2017b) Contamination and health risk assessment of PAHs in soils and crops in industrial areas of the Yangtze River Delta region, China. Chemosphere 168, 976-987. http://doi.org/10.1016/j.chemosphere.2016.10.113

49. Wang, X.-Q., Li, X., Yang, Y.-Y., Fan, L., Han, X., Li, L., Liu, H., Ge, T.-X., Su, L.-Q., Wang, X.-L. and Zhu, Y.-D. (2021a) Source, Characterization of Indoor Dust PAHs and the Health Risk on Chinese Children. Current Medical Science 41(2), 199-210. http://doi.org/10.1007/s11596-021-2337-y

50. Wang, X., Su, L., Wang, Q. and Ma, X. (2021b) Content and source apportionment of polycyclic aromatic hydrocarbons in soil profile (0-100 Cm) of Urumqi petrochemical wastewater irrigation area, China. Soil and Sediment Contamination: An International Journal 30(7), 787-803. http://doi.org/10.1080/15320383.2021.1893645

51. Wang, X.C., Sun, S., Ma, H.Q. and Liu, Y. (2006) Sources and distribution of aliphatic and polyaromatic hydrocarbons in sediments of Jiaozhou Bay, Qingdao, China. Marine Pollution Bulletin 52(2), 129-138. http://doi.org/10.1016/j.marpolbul.2005.08.010 
52. Waqas, M., Khan, S., Chao, C., Shamshad, I., Qamar, Z. and Khan, K. (2014) Quantification of PAHs and health risk via ingestion of vegetable in Khyber Pakhtunkhwa Province, Pakistan. Sci Total Environ 497-498, 448-458. http://doi.org/10.1016/j.scitotenv.2014.07.128

53. Wei, B., Liu, C., Bao, J., Wang, Y., Hu, J., Qi, M., Jin, J. and Wei, Y. (2021) Uptake and distributions of polycyclic aromatic hydrocarbons in cultivated plants around an E-waste disposal site in Southern China. Environ Sci Pollut Res Int 28(3), 2696-2706. http://doi.org/10.1007/s11356-020-10642-1

54. Wu, Y., Yang, L., Zheng, X., Zhang, S., Song, S., Li, J. and Hao, J. (2014) Characterization and source apportionment of particulate PAHs in the roadside environment in Beijing. Science of the Total Environment 470, 76-83. http://doi.org/10.1016/j.scitotenv.2013.09.066

55. Xiong, G., Zhang, Y., Duan, Y., Cai, C., Wang, X., Li, J., Tao, S. and Liu, W. (2017) Uptake of PAHs by cabbage root and leaf in vegetable plots near a large coking manufacturer and associations with PAHs in cabbage core. Environ Sci Pollut Res Int 24(23), 18953-18965. http://doi.org/10.1007/s11356-0179548-6

56. Yang, B., Zhou, L., Xue, N., Li, F., Li, Y., Vogt, R.D., Cong, X., Yan, Y. and Liu, B. (2013) Source apportionment of polycyclic aromatic hydrocarbons in soils of Huanghuai Plain, China: Comparison of three receptor models. Science of the Total Environment 443, 31-39.

http://doi.org/10.1016/j.scitotenv.2012.10.094

57. Yavar Ashayeri, N., Keshavarzi, B., Moore, F., Kersten, M., Yazdi, M. and Lahijanzadeh, A.R. (2018) Presence of polycyclic aromatic hydrocarbons in sediments and surface water from Shadegan wetland - Iran: A focus on source apportionment, human and ecological risk assessment and SedimentWater Exchange. Ecotoxicology and Environmental Safety 148, 1054-1066. http://doi.org/10.1016/j.ecoenv.2017.11.055

58. Zavgorodnyaya, Y.A., Chikidova, A.L., Biryukov, M.V. and Demin, V.V. (2018) Polycyclic aromatic hydrocarbons in atmospheric particulate depositions and urban soils of Moscow, Russia. Journal of Soils and Sediments 19(8), 3155-3165. http://doi.org/10.1007/s11368-018-2067-3

59. Zhang, J., Qu, C., Qi, S., Cao, J., Zhan, C., Xing, X., Xiao, Y., Zheng, J. and Xiao, W. (2015) Polycyclic aromatic hydrocarbons (PAHs) in atmospheric dustfall from the industrial corridor in Hubei Province, Central China. Environmental Geochemistry and Health 37(5), 891-903. http://doi.org/10.1007/s10653-014-9647-y

60. Zheng, H., Qu, C., Zhang, J., Talpur, S.A., Ding, Y., Xing, X. and Qi, S. (2019) Polycyclic aromatic hydrocarbons (PAHs) in agricultural soils from Ningde, China: levels, sources, and human health risk assessment. Environ Geochem Health 41(2), 907-919. http://doi.org/10.1007/s10653-018-0188-7

61. Adetunde, O.T., Mills, G.A., Oluseyi, T.O., Oyeyiola, A.O., Olayinka, K.O. and Alo, B.I. (2018) Polycyclic Aromatic Hydrocarbon in Vegetables Grown on Contaminated Soils in a Sub-Saharan Tropical Environment - Lagos, Nigeria. Polycyclic Aromatic Compounds 40(4), $979-989$. http://doi.org/10.1080/10406638.2018.1517807

62. Anietie, M. and Godwin, E. (2016) Risk Assessment of Polycyclic Aromatic Hydrocarbons PAHs in Soils and Tubers Crops Collected from Ikot Oborenyin, South-south Nigeria. International Research Journal of Pure and Applied Chemistry 10(2), 1-13. http://doi.org/10.9734/irjpac/2016/20154

63. Apiratikul, R., Pongpiachan, S. and Deelaman, W. (2021) Spatial distribution, sources and quantitative human health risk assessments of polycyclic aromatic hydrocarbons in urban and suburban soils of Chile. Environ Geochem Health 43(8), 2851-2870. http://doi.org/10.1007/s10653-020-00798-7

64. Bandowe, B.A.M., Shukurov, N., Leimer, S., Kersten, M., Steinberger, Y. and Wilcke, W. (2021) Polycyclic aromatic hydrocarbons (PAHs) in soils of an industrial area in semi-arid Uzbekistan: spatial distribution, relationship with trace metals and risk assessment. Environ Geochem Health 43(11), 48474861. http://doi.org/10.1007/s10653-021-00974-3

65. Callen, M.S., Iturmendi, A., Lopez, J.M. and Mastral, A.M. (2014) Source apportionment of the carcinogenic potential of polycyclic aromatic hydrocarbons (PAH) associated to airborne PM10 by a PMF model. Environ Sci Pollut Res Int 21(3), 2064-2076. http://doi.org/10.1007/s11356-0132116-9

66. Cao, W., Yin, L., Zhang, D., Wang, Y., Yuan, J., Zhu, Y. and Dou, J. (2019) Contamination, Sources, and Health Risks Associated with Soil PAHs in Rebuilt Land from a Coking Plant, Beijing, China. Int J Environ Res Public Health 16(4). http://doi.org/10.3390/ijerph16040670

67. Chen, W., Wang, H., Gao, Q., Chen, Y., Li, S., Yang, Y., Werner, D., Tao, S. and Wang, X. (2017) Association of 16 priority polycyclic aromatic hydrocarbons with humic acid and humin fractions in a peat soil and implications for their long-term retention. Environ Pollut 230, 882-890. http://doi.org/10.1016/j.envpol.2017.07.038

68. Chen, Y., Zhang, J., Zhang, F., Li, F. and Zhou, M. (2018) Polycyclic aromatic hydrocarbons in farmland soils around main reservoirs of Jilin Province, China: occurrence, sources and potential human health risk. Environ Geochem Health 40(2), 791-802. http://doi.org/10.1007/s10653-017-0024-5

69. De Miguel, E., Iribarren, I., Chacon, E., Ordonez, A. and Charlesworth, S. (2007) Risk-based evaluation of the exposure of children to trace elements in playgrounds in Madrid (Spain). Chemosphere 66(3), 505-513. http://doi.org/10.1016/j.chemosphere.2006.05.065

70. Dong, T.T.T. and Lee, B.-K. (2009) Characteristics, toxicity, and source apportionment of polycylic aromatic hydrocarbons (PAHs) in road dust of Ulsan, Korea. Chemosphere 74(9), 1245-1253. http://doi.org/10.1016/j.chemosphere.2008.11.035

71. Dong, W. and Yang, Y. (2014) Exploitation of mineral resource and its influence on regional development and urban evolution in Xinjiang, China. Journal of Geographical Sciences 24(6), 1131-1146. http://doi.org/10.1007/s11442-014-1143-x

72. Fan, Y., Zhao, Z., Shi, R., Li, X., Yang, Y. and Lan, J. (2021) Urbanization-related changes over the last 20 years in occurrence, sources, and human health risks of soil PAHs in rural Tianjin, China. Environmental Chemistry Letters 19(6), 3999-4008. http://doi.org/10.1007/s10311-021-01264-1

73. Fang, G.C., Chang, K.F., Lu, C.S. and Bai, H.L. (2004) Estimation of PAHs dry deposition and BaP toxic equivalency factors (TEFs) study at Urban, Industry Park and rural sampling sites in central Taiwan, Taichung. Chemosphere 55(6), 787-796. http://doi.org/10.1016/j.chemosphere.2003.12.012

74. Ge, W., Cheng, Q.-q., Chai, C., Zeng, L.-s., Wu, J., Chen, Q.-h., Zhu, X.-w. and Ma, D. (2017) Pollution Characteristics and Source Analysis of Polycyclic Aromatic Hydrocarbons in Agricultural Soils from Shandong. Huanjing Kexue 38(4), 1587-1596. http://doi.org/10.13227/j.hjkx.201608199 
75. Hu, J., Liu, C., Guo, Q., Yang, J., Okoli, C.P., Lang, Y., Zhao, Z., Li, S., Liu, B. and Song, G. (2017) Characteristics, source, and potential ecological risk assessment of polycyclic aromatic hydrocarbons (PAHs) in the Songhua River Basin, Northeast China. Environmental Science and Pollution Research 24(20), 17090-17102. http://doi.org/10.1007/s11356-017-9057-7

76. Islam, N. and Saikia, B.K. (2020) Atmospheric particulate matter and potentially hazardous compounds around residential/road side soil in an urban area. Chemosphere 259, 127453. http://doi.org/10.1016/j.chemosphere.2020.127453

77. Jeba, F., Karim, T.T., Khan, M.F., Latif, M.T., Quddus, K.F. and Salam, A. (2021) Receptor modelling and risk factors of polycyclic aromatic hydrocarbons (PAHs) in the atmospheric particulate matter at an IGP outflow location (island of the bay of Bengal-Bhola, Bangladesh). Air Quality, Atmosphere \& Health 14(9), 1417-1431. http://doi.org/10.1007/s11869-021-01031-9

78. Jia, J., Bi, C., Zhang, J., Jin, X. and Chen, Z. (2018) Characterization of polycyclic aromatic hydrocarbons (PAHs) in vegetables near industrial areas of Shanghai, China: Sources, exposure, and cancer risk. Environ Pollut 241, 750-758. http://doi.org/10.1016/j.envpol.2018.06.002

79. Jia, T., Guo, W., Xing, Y., Lei, R., Wu, X., Sun, S., He, Y. and Liu, W. (2021) Spatial distributions and sources of PAHs in soil in chemical industry parks in the Yangtze River Delta, China. Environ Pollut 283, 117121. http://doi.org/10.1016/j.envpol.2021.117121

80. Khairy, M.A. and Lohmann, R. (2013) Source apportionment and risk assessment of polycyclic aromatic hydrocarbons in the atmospheric environment of Alexandria, Egypt. Chemosphere 91(7), 895-903. http://doi.org/10.1016/j.chemosphere.2013.02.018

81. Li, S. and Xie, S. (2016) Spatial distribution and source analysis of SO2 concentration in Urumqi. International Journal of Hydrogen Energy 41(35), 15899-15908. http://doi.org/10.1016/j.ijhydene.2016.04.142

82. Liang, M., Liang, H., Rao, Z. and Hong, X. (2019) Characterization of polycyclic aromatic hydrocarbons in urban-rural integration area soil, North China: Spatial distribution, sources and potential human health risk assessment. Chemosphere 234, 875-884. http://doi.org/10.1016/j.chemosphere.2019.06.119

83. Liao, C.M. and Chiang, K.C. (2006) Probabilistic risk assessment for personal exposure to carcinogenic polycyclic aromatic hydrocarbons in Taiwanese temples. Chemosphere 63(9), 1610-1619. http://doi.org/10.1016/j.chemosphere.2005.08.051

84. Liu, H., Yu, X.L., Liu, Z.R. and Sun, Y. (2018) Occurrence, characteristics and sources of polycyclic aromatic hydrocarbons in arable soils of Beijing, China. Ecotoxicology and Environmental Safety 159, 120-126. http://doi.org/10.1016/j.ecoenv.2018.04.069

85. Liu, N., Li, X., Zhang, D., Liu, Q., Xiang, L., Liu, K., Yan, D. and Li, Y. (2017a) Distribution, sources, and ecological risk assessment of polycyclic aromatic hydrocarbons in surface sediments from the Nantong Coast, China. Marine Pollution Bulletin 114(1), 571-576.

http://doi.org/10.1016/j.marpolbul.2016.09.020

86. Liu, W., Ma, L., Abuduwaili, J. and Li, Y. (2017b) Distribution, source analysis, and ecological risk assessment of polycyclic aromatic hydrocarbons in the typical topsoil of the Issyk-Kul Lake Basin. Environ Monit Assess 189(8), 398. http://doi.org/10.1007/s10661-017-6113-1

87. Lu, J., Zhang, C., Wu, J., Lin, Y., Zhang, Y., Yu, X. and Zhang, Z. (2019) Pollution, sources, and ecological-health risks of polycyclic aromatic hydrocarbons in coastal waters along coastline of China. Human and Ecological Risk Assessment: An International Journal 26(4), 968-985. http://doi.org/10.1080/10807039.2018.1548899

88. Maertens, R.M., Yang, X.F., Zhu, J.P., Gagne, R.W., Douglas, G.R. and White, P.A. (2008) Mutagenic and carcinogenic hazards of settled house dust I: Polycyclic aromatic hydrocarbon content and excess lifetime cancer risk from preschool exposure. Environmental Science \& Technology 42(5), 17471753. http://doi.org/10.1021/es702449c

89. Magesh, N.S., Tiwari, A., Botsa, S.M. and da Lima Leitao, T. (2021) Hazardous heavy metals in the pristine lacustrine systems of Antarctica: Insights from PMF model and ERA techniques. J Hazard Mater 412, 125263. http://doi.org/10.1016/j.jhazmat.2021.125263

90. Mamtimin, B. and Meixner, F.X. (2011) Air pollution and meteorological processes in the growing dryland city of Urumqi (Xinjiang, China). Sci Total Environ 409(7), 1277-1290. http://doi.org/10.1016/j.scitotenv.2010.12.010

91. Manoli, E., Kouras, A. and Samara, C. (2004) Profile analysis of ambient and source emitted particle-bound polycyclic aromatic hydrocarbons from three sites in northern Greece. Chemosphere 56(9), 867-878. http://doi.org/10.1016/j.chemosphere.2004.03.013

92. Mungai, T.M., Yan, X., Makokha, V.A., Githaiga, K.B. and Wang, J. (2018) Concentrations, source identification and eco-toxicological risk of polycyclic aromatic hydrocarbons in agricultural soils of Kenya, Eastern Africa. International Journal of Environmental Science and Technology 16(8), $4303-4314$. http://doi.org/10.1007/s13762-018-2014-2

93. Nadal, M., Schuhmacher, M. and Domingo, J.L. (2004) Levels of PAHs in soil and vegetation samples from Tarragona County, Spain. Environmental Pollution 132(1), 1-11. http://doi.org/10.1016/j.envpol.2004.04.003

94. Paris, A., Ledauphin, J., Poinot, P. and Gaillard, J.L. (2018) Polycyclic aromatic hydrocarbons in fruits and vegetables: Origin, analysis, and occurrence. Environ Pollut 234, 96-106. http://doi.org/10.1016/j.envpol.2017.11.028

95. Peng, C., Chen, W., Liao, X., Wang, M., Ouyang, Z., Jiao, W. and Bai, Y. (2011a) Polycyclic aromatic hydrocarbons in urban soils of Beijing: status, sources, distribution and potential risk. Environ Pollut 159(3), 802-808. http://doi.org/10.1016/j.envpol.2010.11.003

96. Peng, C., Chen, W., Liao, X., Wang, M., Ouyang, Z., Jiao, W. and Bai, Y. (2011b) Polycyclic aromatic hydrocarbons in urban soils of Beijing: Status, sources, distribution and potential risk. Environmental Pollution 159(3), 802-808. http://doi.org/10.1016/j.envpol.2010.11.003

97. Qi, P., Qu, C., Albanese, S., Lima, A., Cicchella, D., Hope, D., Cerino, P., Pizzolante, A., Zheng, H., Li, J. and De Vivo, B. (2020)Investigation of polycyclic aromatic hydrocarbons in soils from Caserta provincial territory, southern Italy: Spatial distribution, source apportionment, and risk assessment. Journal of Hazardous Materials 383, 121158. http://doi.org/10.1016/j.jhazmat.2019.121158 
98. Shahsavani, S., Hoseini, M., Dehghani, M. and Fararouei, M. (2017) Characterisation and potential source identification of polycyclic aromatic hydrocarbons in atmospheric particles (PM10) from urban and suburban residential areas in Shiraz, Iran. Chemosphere 183, 557-564.

http://doi.org/10.1016/j.chemosphere.2017.05.101

99. Shen, G., Wang, W., Yang, Y., Ding, J., Xue, M., Min, Y., Zhu, C., Shen, H., Li, W., Wang, B., Wang, R., Wang, X., Tao, S. and Russell, A.G. (2011) Emissions of PAHs from Indoor Crop Residue Burning in a Typical Rural Stove: Emission Factors, Size Distributions, and Gas-Particle Partitioning. Environmental Science \& Technology 45(4), 1206-1212. http://doi.org/10.1021/es102151w

100. Simayi, M., Yahefu, P. and Han, M. (2018) Spatiotemporal Variation, Source Analysis, and Health Risk Assessment of Particle-bound PAHs in Urumqi, China. Aerosol and Air Quality Research 18(11), 2728-2740. http://doi.org/10.4209/aaqr.2018.04.0151

101. Soltani, N., Keshavarzi, B., Moore, F., Tavakol, T., Lahijanzadeh, A.R., Jaafarzadeh, N. and Kermani, M. (2015) Ecological and human health hazards of heavy metals and polycyclic aromatic hydrocarbons (PAHs) in road dust of Isfahan metropolis, Iran. Science of the Total Environment 505, 712-723. http://doi.org/10.1016/j.scitotenv.2014.09.097

102. Stańczyk-Mazanek, E., Stępniak, L. and Kępa, U. (2019) Analysis of Migration of Polycyclic Aromatic Hydrocarbons from Sewage Sludge Used for Fertilization to Soils, Surface Waters, and Plants. Water 11(6), 1270. http://doi.org/10.3390/w11061270

103. Tesi, G.O., Iniaghe, P.O., Lari, B., Obi-lyeke, G. and Ossai, J.C. (2021) Polycyclic aromatic hydrocarbons (PAHs) in leafy vegetables consumed in southern Nigeria: concentration, risk assessment and source apportionment. Environ Monit Assess 193(7), 443. http://doi.org/10.1007/s10661-021-09217-5

104. Tong, R., Yang, X., Su, H., Pan, Y., Zhang, Q., Wang, J. and Long, M. (2018) Levels, sources and probabilistic health risks of polycyclic aromatic hydrocarbons in the agricultural soils from sites neighboring suburban industries in Shanghai. Sci Total Environ 616-617, 1365-1373. http://doi.org/10.1016/j.scitotenv.2017.10.179

105. Tesi, G.O., Iniaghe, P.O., Lari, B., Obi-lyeke, G. and Ossai, J.C. (2021) Polycyclic aromatic hydrocarbons (PAHs) in leafy vegetables consumed in southern Nigeria: concentration, risk assessment and source apportionment. Environ Monit Assess 193(7), 443. http://doi.org/10.1007/s10661-021-09217-5

106. Tsai, P.J., Shieh, H.Y., Lee, W.J. and Lai, S.O. (2001) Health-risk assessment for workers exposed to polycyclic aromatic hydrocarbons (PAHs) in a carbon black manufacturing industry. Science of the Total Environment 278(1-3), 137-150. http://doi.org/10.1016/s0048-9697(01)00643-x

107. Wang, C., Wu, S., Zhou, S.L., Wang, H., Li, B., Chen, H., Yu, Y. and Shi, Y. (2015) Polycyclic aromatic hydrocarbons in soils from urban to rural areas in Nanjing: Concentration, source, spatial distribution, and potential human health risk. Sci Total Environ 527-528, 375-383.

http://doi.org/10.1016/j.scitotenv.2015.05.025

108. Wang, C.H., Wu, S.H., Zhou, S.L., Sill, Y.X. and Song, J. (2017a) Characteristics and Source Identification of Polycyclic Aromatic Hydrocarbons (PAHs) in Urban Soils: A Review. Pedosphere 27(1), 17-26. http://doi.org/10.1016/s1002-0160(17)60293-5

109. Wang, J., Zhang, X., Ling, W., Liu, R., Liu, J., Kang, F. and Gao, Y. (2017b) Contamination and health risk assessment of PAHs in soils and crops in industrial areas of the Yangtze River Delta region, China. Chemosphere 168, 976-987. http://doi.org/10.1016/j.chemosphere.2016.10.113

110. Wang, X.-Q., Li, X., Yang, Y.-Y., Fan, L., Han, X., Li, L., Liu, H., Ge, T.-X., Su, L.-Q., Wang, X.-L. and Zhu, Y.-D. (2021a) Source, Characterization of Indoor Dust PAHs and the Health Risk on Chinese Children. Current Medical Science 41(2), 199-210. http://doi.org/10.1007/s11596-021-2337-y

111. Wang, X., Su, L., Wang, Q. and Ma, X. (2021b) Content and source apportionment of polycyclic aromatic hydrocarbons in soil profile (0-100 Cm) of Urumqi petrochemical wastewater irrigation area, China. Soil and Sediment Contamination: An International Journal 30(7), 787-803. http://doi.org/10.1080/15320383.2021.1893645

112. Wang, X.C., Sun, S., Ma, H.Q. and Liu, Y. (2006) Sources and distribution of aliphatic and polyaromatic hydrocarbons in sediments of Jiaozhou Bay, Qingdao, China. Marine Pollution Bulletin 52(2), 129-138. http://doi.org/10.1016/j.marpolbul.2005.08.010

113. Waqas, M., Khan, S., Chao, C., Shamshad, I., Qamar, Z. and Khan, K. (2014) Quantification of PAHs and health risk via ingestion of vegetable in Khyber Pakhtunkhwa Province, Pakistan. Sci Total Environ 497-498, 448-458. http://doi.org/10.1016/j.scitotenv.2014.07.128

114. Wei, B., Liu, C., Bao, J., Wang, Y., Hu, J., Qi, M., Jin, J. and Wei, Y. (2021) Uptake and distributions of polycyclic aromatic hydrocarbons in cultivated plants around an E-waste disposal site in Southern China. Environ Sci Pollut Res Int 28(3), 2696-2706. http://doi.org/10.1007/s11356-020-10642-1

115. Wu, Y., Yang, L., Zheng, X., Zhang, S., Song, S., Li, J. and Hao, J. (2014) Characterization and source apportionment of particulate PAHs in the roadside environment in Beijing. Science of the Total Environment 470, 76-83. http://doi.org/10.1016/j.scitotenv.2013.09.066

116. Xiong, G., Zhang, Y., Duan, Y., Cai, C., Wang, X., Li, J., Tao, S. and Liu, W. (2017) Uptake of PAHs by cabbage root and leaf in vegetable plots near a large coking manufacturer and associations with PAHs in cabbage core. Environ Sci Pollut Res Int 24(23), 18953-18965. http://doi.org/10.1007/s11356-0179548-6

117. Yang, B., Zhou, L., Xue, N., Li, F., Li, Y., Vogt, R.D., Cong, X., Yan, Y. and Liu, B. (2013) Source apportionment of polycyclic aromatic hydrocarbons in soils of Huanghuai Plain, China: Comparison of three receptor models. Science of the Total Environment 443, 31-39.

http://doi.org/10.1016/j.scitotenv.2012.10.094

118. Yavar Ashayeri, N., Keshavarzi, B., Moore, F., Kersten, M., Yazdi, M. and Lahijanzadeh, A.R. (2018) Presence of polycyclic aromatic hydrocarbons in sediments and surface water from Shadegan wetland - Iran: A focus on source apportionment, human and ecological risk assessment and SedimentWater Exchange. Ecotoxicology and Environmental Safety 148, 1054-1066. http://doi.org/10.1016/j.ecoenv.2017.11.055

119. Zavgorodnyaya, Y.A., Chikidova, A.L., Biryukov, M.V. and Demin, V.V. (2018) Polycyclic aromatic hydrocarbons in atmospheric particulate depositions and urban soils of Moscow, Russia. Journal of Soils and Sediments 19(8), 3155-3165. http://doi.org/10.1007/s11368-018-2067-3

120. Zhang, J., Qu, C., Qi, S., Cao, J., Zhan, C., Xing, X., Xiao, Y., Zheng, J. and Xiao, W. (2015) Polycyclic aromatic hydrocarbons (PAHs) in atmospheric dustfall from the industrial corridor in Hubei Province, Central China. Environmental Geochemistry and Health 37(5), 891-903.

http://doi.org/10.1007/s10653-014-9647-y

Page 11/17 
121. Zheng, H., Qu, C., Zhang, J., Talpur, S.A., Ding, Y., Xing, X. and Qi, S. (2019) Polycyclic aromatic hydrocarbons (PAHs) in agricultural soils from Ningde, China: levels, sources, and human health risk assessment. Environ Geochem Health 41(2), 907-919. http://doi.org/10.1007/s10653-018-0188-7

122. Zou, Y., Liu, J., Liu, X. and Jia, J. (2021) Health risk assessment of polycyclic aromatic hydrocarbons (PAHs) in the soil around thermal power plants in southwest China. J Environ Sci Health A Tox Hazard Subst Environ Eng 56(7), 786-796. http://doi.org/10.1080/10934529.2021.1927597

\section{Tables}

\section{Table 1}

The method detection limits (MDL) of different samples (ng/g)

\begin{tabular}{|llll|}
\hline Method Detection LimitヌMDL】 & Abbrev. & Soil samples & Crop samples \\
\hline Naphthalene & NAPH & 0.13 & 0.52 \\
\hline Acenaphthylene & ACY & 0.0061 & 0.15 \\
\hline Acenaphthene & ACE & 0.0013 & 0.131 \\
\hline Fluorene & FLU & 0.025 & 0.64 \\
\hline Phenanthrene & PHE & 0.0064 & 0.12 \\
\hline Anthracene & ANT & 0.095 & 0.21 \\
\hline Fluoranthene & FLA & 0.033 & 0.085 \\
\hline Pyrene & PYR & 0.041 & 0.11 \\
\hline Benzo[a]anthracene & BaA & 0.019 & 0.071 \\
\hline Chrysene & CHR & 0.0092 & 0.014 \\
\hline Benzo[b]fluoranthene & BbF & 0.013 & 0.0451 \\
\hline Benzo[k]fluoranthene & BkF & 0.015 & 0.018 \\
\hline Benzo[a]pyrene & BaP & 0.0018 & 0.0063 \\
\hline Indeno[1,2,3-cd]pyene & InP & 0.0026 & 0.0091 \\
\hline Benzo[ghi]perylene & BghiP & 0.0025 & 0.13 \\
\hline Dibenz[a,h]anthracene & DBA & 0.0072 & 0.021 \\
\hline
\end{tabular}

\section{Table 2}

Concentrations of 51 soil samples in Midong industrial zone (unit:ng/g) 
Concentrations of 51 soil samples in Midong industrial zone (unit:ng/g)

\begin{tabular}{cccccccc}
\hline $\begin{array}{c}\text { Soil Samples) } \\
\text { PAHs }\end{array}$ & Abbrev. & Min & Max & Mean & Median & Sum & $\begin{array}{c}\text { Detectable } \\
\text { Ratio(\%) }\end{array}$ \\
\hline Naphthalene & NAPH & 0.02 & 4.44 & 0.67 & 0.90 & 45.85 & $94.12 \%$ \\
Acenaphthylene & ACY & ND & 1.10 & 0.19 & 0.21 & 10.82 & $92.16 \%$ \\
Acenaphthene & ACE & ND & 0.95 & 0.38 & 0.39 & 20.03 & $98.04 \%$ \\
Fluorene & FLU & 0.03 & 4.82 & 1.38 & 1.48 & 75.51 & $98.04 \%$ \\
Phenanthrene & PHE & 0.81 & 39.76 & 9.98 & 10.56 & 538.46 & $100.00 \%$ \\
Anthracene & ANT & 0.40 & 7.83 & 2.48 & 2.82 & 143.74 & $100.00 \%$ \\
Fluoranthene & FLA & 0.04 & 29.64 & 4.87 & 5.85 & 298.53 & $98.04 \%$ \\
Pyrene & PYR & 0.06 & 16.17 & 3.21 & 3.48 & 177.24 & $92.16 \%$ \\
Benzo[a]anthracene & BaA & 0.02 & 26.34 & 2.53 & 3.55 & 181.12 & $98.04 \%$ \\
Chrysene & CHR & 0.03 & 21.35 & 3.10 & 3.81 & 194.56 & $96.08 \%$ \\
Benzo[b]fluoranthene & BbF & 0.03 & 18.85 & 2.48 & 3.78 & 192.93 & $98.04 \%$ \\
Benzo[k]fluoranthene & BkF & 0.02 & 15.04 & 3.15 & 3.85 & 196.26 & $98.04 \%$ \\
Benzo[a]pyrene & BaP & 0.03 & 12.97 & 1.63 & 2.25 & 114.54 & $96.08 \%$ \\
Indeno[1,2,3-cd]pyene & InP & 0.10 & 9.46 & 0.66 & 1.32 & 67.41 & $72.55 \%$ \\
Benzo[ghi]perylene & BghiP & 0.68 & 12.93 & 2.16 & 3.02 & 153.78 & $86.27 \%$ \\
Dibenz[a,h]anthracene & DahA & 0.07 & 3.47 & 0.40 & 0.60 & 30.51 & $72.55 \%$ \\
$\sum_{16} P A H s$ & & 2.32 & 225.11 & 39.29 & 47.87 & 2441.29 & \\
\hline A & & & & & & &
\end{tabular}

Annotation: ND means not detected.

Table 3

Concentrations of crop samples in Midong industrial zone (unit:ng/g)

\begin{tabular}{|c|c|c|c|c|c|c|c|c|c|c|c|}
\hline 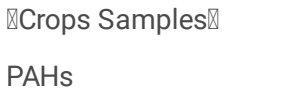 & Onion & $\begin{array}{l}\text { Onion } \\
\text { root }\end{array}$ & Cabbage & Coriander & Beans & Spinach & Celery & Lettuce & $\begin{array}{l}\text { Sunflower } \\
\text { fruit }\end{array}$ & $\begin{array}{l}\text { Sunflower } \\
\text { leaves }\end{array}$ & $\begin{array}{l}\text { Sunflower } \\
\text { root }\end{array}$ \\
\hline Naphthalene & 82.06 & 18.63 & 7.36 & 12.67 & 7.17 & 20.57 & 13.58 & 18.31 & 11.15 & 20.02 & 23.76 \\
\hline Acenaphthylene & 12.71 & 7.67 & 3.94 & 3.54 & 2.44 & 3.21 & 3.25 & 2.98 & 3.37 & 9.30 & 6.84 \\
\hline Acenaphthene & 30.05 & 17.59 & 7.42 & 8.69 & 10.11 & 6.36 & 8.61 & 5.35 & 4.52 & 24.11 & 9.43 \\
\hline Fluorene & 109.01 & 79.69 & 38.27 & 27.27 & 26.47 & 26.74 & 20.25 & 26.35 & 29.50 & 44.35 & 34.91 \\
\hline Phenanthrene & 208.56 & 181.11 & 225.42 & 96.84 & 136.48 & 106.99 & 60.23 & 222.84 & 135.64 & 178.74 & 152.80 \\
\hline Anthracene & 11.95 & 13.31 & 19.93 & 6.83 & 9.46 & 9.37 & 5.10 & 11.97 & 3.48 & 13.89 & 6.55 \\
\hline Fluoranthene & 25.49 & 26.36 & 36.06 & 16.33 & 28.80 & 19.39 & 11.84 & 42.27 & 30.01 & 27.47 & 26.86 \\
\hline Pyrene & 15.38 & 15.55 & 19.31 & 11.42 & 14.82 & 10.83 & 5.81 & 21.98 & 23.70 & 23.12 & 18.04 \\
\hline Benzo[a]anthracene & 1.14 & 0.51 & 0.27 & 0.71 & 0.58 & 0.99 & ND & ND & 1.33 & 1.46 & 1.07 \\
\hline Chrysene & 3.72 & 4.31 & 3.77 & 4.10 & 3.30 & 2.20 & 1.92 & 4.17 & 3.63 & 4.60 & 3.33 \\
\hline Benzo[b]fluoranthene & 2.08 & 0.70 & 0.13 & 0.60 & 0.39 & 1.33 & 0.59 & ND & 0.41 & 2.32 & ND \\
\hline Benzo[k]fluoranthene & 0.54 & 0.58 & 0.36 & 0.77 & 0.70 & 0.84 & 0.43 & 0.55 & 0.65 & 1.51 & 0.69 \\
\hline Benzo[a]pyrene & 0.53 & 0.12 & 0.32 & 0.43 & 0.45 & 0.32 & 0.20 & 0.05 & 0.07 & 0.59 & 0.31 \\
\hline Indeno[1,2,3-cd]pyene & 0.30 & 0.25 & 0.17 & 0.29 & 0.19 & 0.22 & ND & ND & ND & ND & ND \\
\hline Benzo[ghi]perylene & ND & ND & ND & ND & ND & ND & ND & ND & ND & ND & ND \\
\hline \multirow[t]{2}{*}{ Dibenz[a,h]anthracene } & 0.92 & 0.35 & 0.61 & 0.82 & 0.76 & 1.32 & 0.65 & 0.37 & 0.49 & 1.16 & 0.53 \\
\hline & 504.43 & 366.72 & 363.33 & 191.32 & 242.12 & 210.69 & 132.44 & 357.18 & 247.95 & 352.64 & 285.13 \\
\hline
\end{tabular}

Annotation:ND means not detected. 


\section{Table 4}

TEQ value of PAHs in farmland soil samples

\begin{tabular}{|llll|}
\hline & TEF & & TEQ \\
\hline NAPH & 0.0010 & 45.85 & 0.05 \\
\hline ACY & 0.0010 & 10.82 & 0.01 \\
\hline ACE & 0.0010 & 20.03 & 0.02 \\
\hline FLU & 0.0010 & 75.51 & 0.08 \\
\hline PHE & 0.0010 & 538.46 & 0.54 \\
\hline ANT & 0.0010 & 143.74 & 0.14 \\
\hline FLA & 0.0010 & 298.53 & 0.30 \\
\hline PYR & 0.0010 & 177.24 & 0.18 \\
\hline BaA & 0.1000 & 181.12 & 18.11 \\
\hline CHR & 0.0100 & 194.56 & 1.95 \\
\hline BbF & 0.1000 & 192.93 & 19.29 \\
\hline BkF & 0.1000 & 196.26 & 19.63 \\
\hline BaP & 1.0000 & 114.54 & 114.54 \\
\hline InP & 0.1000 & 67.41 & 6.74 \\
\hline BghiP & 0.0100 & 153.78 & 1.54 \\
\hline DBA & 1.0000 & 30.51 & 30.51 \\
\hline Sum & & & 213.61 \\
\hline
\end{tabular}

\section{Table 5}

Carcinogenic risk of PAHs in soil to different populations

\begin{tabular}{|c|c|c|c|c|c|c|}
\hline \multirow[b]{2}{*}{ Different groups } & \multicolumn{2}{|c|}{ ILCR of ingestion } & \multicolumn{2}{|c|}{ ILCR of dermal } & \multicolumn{2}{|c|}{ ILCR of inhalation } \\
\hline & children & adult & children & adult & children & adult \\
\hline ILCRs & $1.03 \times 10^{-5}$ & $8.05 \times 10^{-6}$ & $1.00 \times 10^{-8}$ & $1.05 \times 10^{-8}$ & $1.46 \times 10^{-10}$ & $6.20 \times 10^{-10}$ \\
\hline
\end{tabular}

\section{Table 6}

Daily exposure of PAHs in crops to different populations

\begin{tabular}{|c|c|c|c|c|c|c|}
\hline \multirow[t]{2}{*}{ Daily exposure (ng/g·kg) } & \multicolumn{2}{|c|}{ children } & \multicolumn{2}{|c|}{ teenagers } & \multicolumn{2}{|l|}{ adult } \\
\hline & male & female & male & female & male & female \\
\hline Onion & 1.73 & 1.79 & 0.89 & 1.19 & 1.38 & 1.48 \\
\hline Cabbage & 0.55 & 0.58 & 0.29 & 0.38 & 0.44 & 0.47 \\
\hline Coriander & 0.95 & 0.99 & 0.49 & 0.66 & 0.76 & 0.82 \\
\hline Beans & 1.68 & 1.74 & 0.86 & 1.16 & 1.34 & 1.43 \\
\hline Spinach & 1.96 & 2.04 & 1.01 & 1.36 & 1.57 & 1.68 \\
\hline Celery & 0.86 & 0.89 & 0.44 & 0.59 & 0.69 & 0.74 \\
\hline Lettuce & 0.44 & 0.45 & 0.23 & 0.30 & 0.35 & 0.37 \\
\hline Sunflower & 1.08 & 4.09 & 4.25 & 2.11 & 2.83 & 3.28 \\
\hline
\end{tabular}

\section{Table 7}

Carcinogenic risk of PAHs in crops for different populations 


\begin{tabular}{|lllllll|}
\hline & children & & teenagers & \multicolumn{3}{c|}{ adult } \\
\hline ILCR & male & female & male & female & male & female \\
\hline Onion & $5.97 \times 10^{-6}$ & $6.18 \times 10^{-6}$ & $5.57 \times 10^{-7}$ & $7.44 \times 10^{-7}$ & $7.65 \times 10^{-6}$ & $8.20 \times 10^{-6}$ \\
\hline Cabbage & $1.90 \times 10^{-6}$ & $2.00 \times 10^{-6}$ & $1.81 \times 10^{-7}$ & $2.38 \times 10^{-7}$ & $2.44 \times 10^{-6}$ & $2.60 \times 10^{-6}$ \\
\hline Coriander & $3.28 \times 10^{-6}$ & $3.42 \times 10^{-6}$ & $3.06 \times 10^{-7}$ & $4.13 \times 10^{-7}$ & $4.21 \times 10^{-6}$ & $4.54 \times 10^{-6}$ \\
\hline Beans & $5.80 \times 10^{-6}$ & $6.00 \times 10^{-6}$ & $5.38 \times 10^{-7}$ & $7.25 \times 10^{-7}$ & $7.42 \times 10^{-6}$ & $7.92 \times 10^{-6}$ \\
\hline Spinach & $6.76 \times 10^{-6}$ & $7.04 \times 10^{-6}$ & $6.32 \times 10^{-7}$ & $8.50 \times 10^{-7}$ & $8.70 \times 10^{-6}$ & $9.31 \times 10^{-6}$ \\
\hline Celery & $2.97 \times 10^{-6}$ & $3.07 \times 10^{-6}$ & $2.75 \times 10^{-7}$ & $3.69 \times 10^{-7}$ & $3.82 \times 10^{-6}$ & $4.10 \times 10^{-6}$ \\
\hline Lettuce & $1.52 \times 10^{-6}$ & $1.55 \times 10^{-6}$ & $1.44 \times 10^{-7}$ & $1.88 \times 10^{-7}$ & $1.94 \times 10^{-6}$ & $2.05 \times 10^{-6}$ \\
\hline Sunflower & $1.41 \times 10^{-5}$ & $1.47 \times 10^{-5}$ & $1.32 \times 10^{-5}$ & $1.77 \times 10^{-5}$ & $1.82 \times 10^{-5}$ & $1.94 \times 10^{-5}$ \\
\hline
\end{tabular}

\section{Figures}

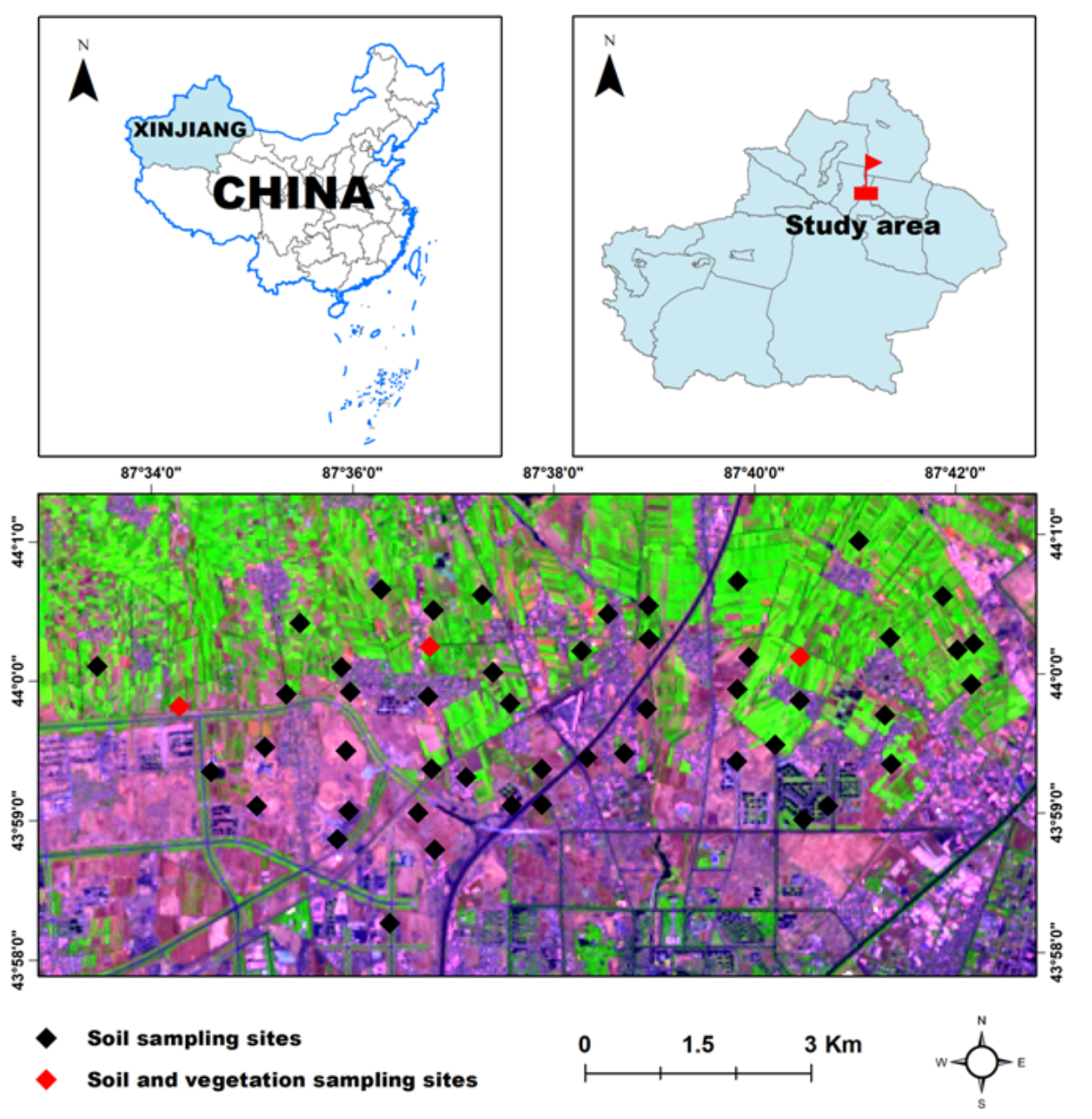

Figure 1

Distribution of farmland soil and crop sampling sites near Midong Industrial Park, Urumqi city (Use ArcGIS to get the graph) 


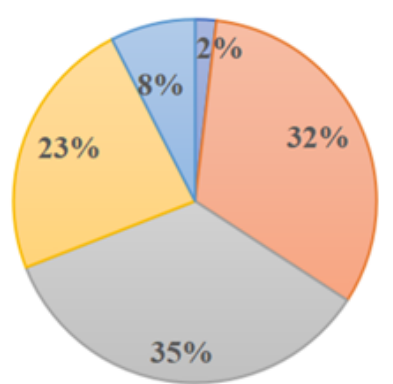

Soil samples

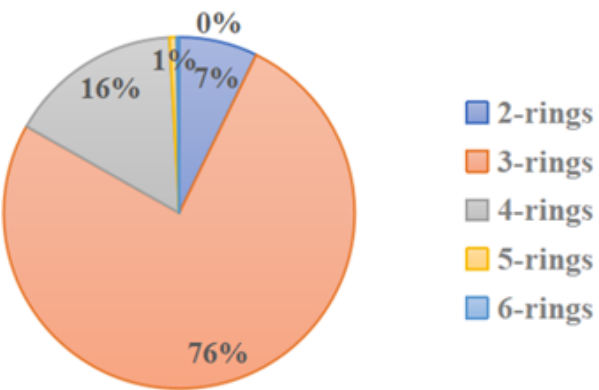

Crop samples

\section{Figure 2}

Percentage of PAHs with different ring numbers in soil and crop samples (Use Orange to get the graph)

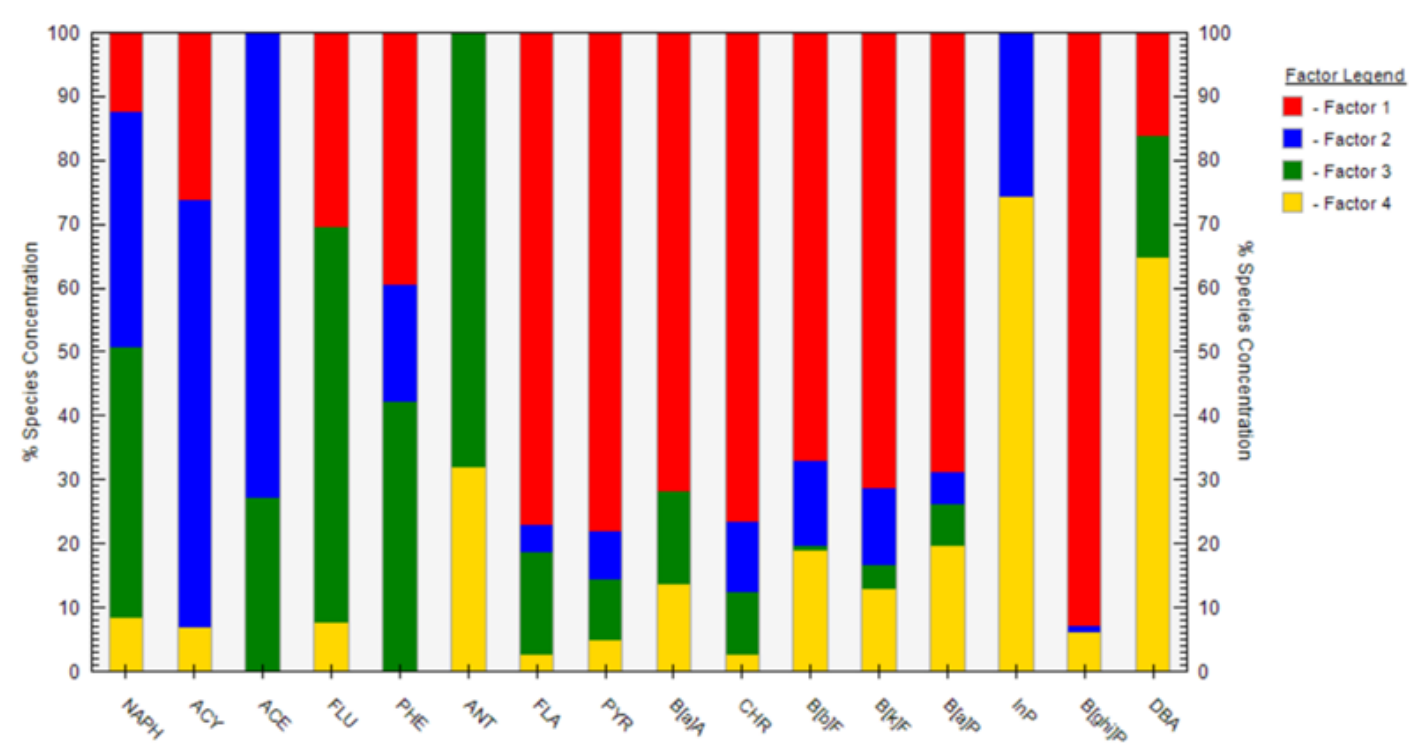

\section{Figure 3}

Factor fingerprint spectrum of PAHs in soil analyzed by PMF model at four factor number (Using the PMF model)

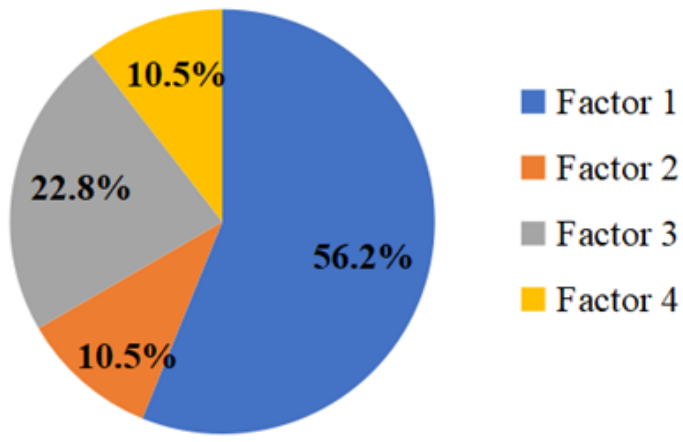

\section{Figure 4}

Contribution rate of PMF model to four sources of PAHs in soil (Use Orange to get the graph) 
Factor 1
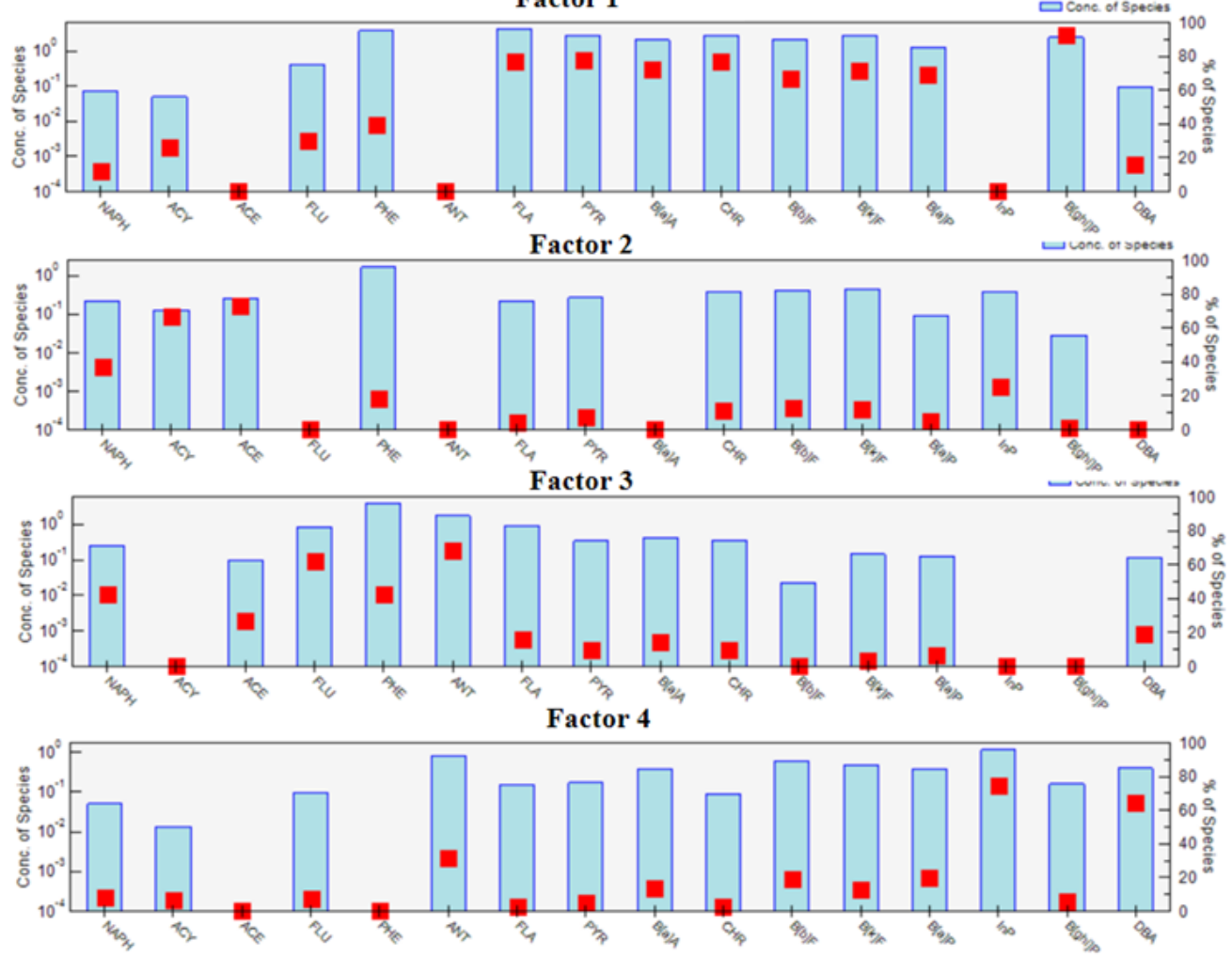

Figure 5

Source apportionment component spectrum of PAHs in soil under four factors by PMF model (Using the PMF model)
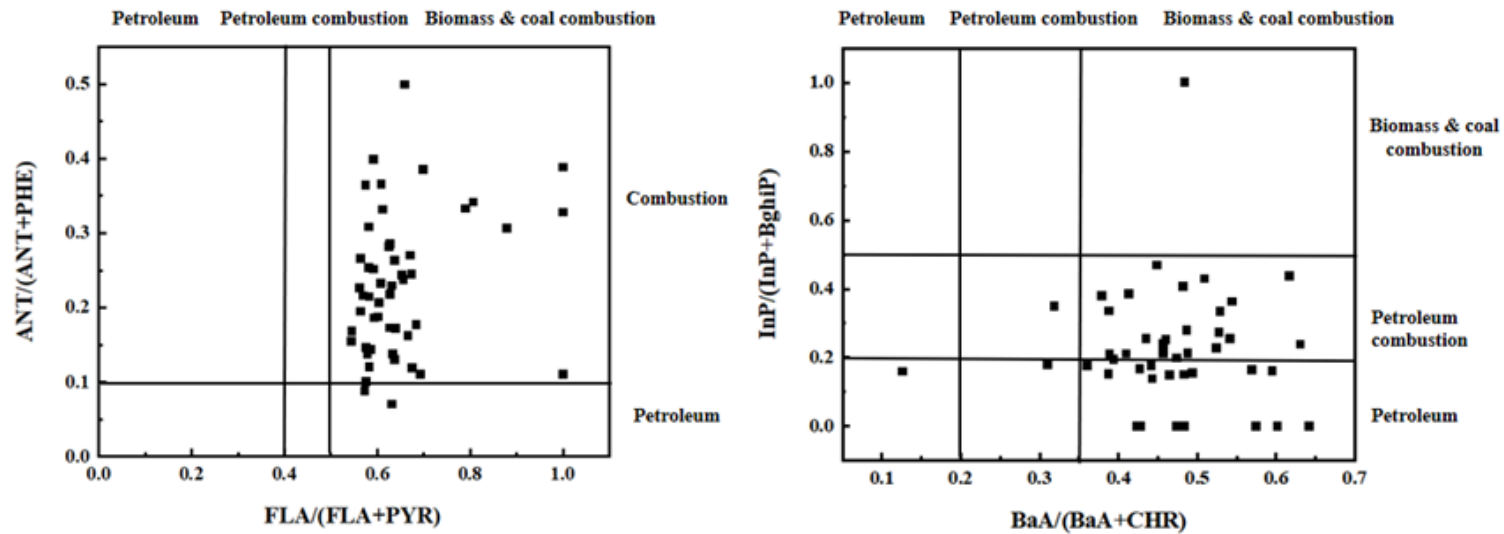

Figure 6

The ratio method was used for qualitative analysis of the sources of PAHs in soil (Use Orange to get the graph) 